\title{
Effects of the Wegener-Bergeron-Findeisen process on global black carbon distribution
}

\author{
Ling $\mathbf{Q i}^{1,2}$, Qinbin $\mathrm{Li}^{1,2}$, Cenlin $\mathrm{He}^{1,2}$, Xin Wang ${ }^{3}$, and Jianping Huang ${ }^{3}$ \\ ${ }^{1}$ Department of Atmospheric and Oceanic Sciences, University of California, Los Angeles, CA, USA \\ ${ }^{2}$ Joint Institute for Regional Earth System Science and Engineering, University of California, Los Angeles, CA, USA \\ ${ }^{3}$ Key Laboratory for Semi-Arid Climate Change of the Ministry of Education, College of Atmospheric Sciences, \\ Lanzhou University, Lanzhou, China \\ Correspondence to: Ling Qi (qiling@atmos.ucla.edu)
}

Received: 5 August 2016 - Discussion started: 28 September 2016

Revised: 28 March 2017 - Accepted: 30 March 2017 - Published: 21 June 2017

\begin{abstract}
We systematically investigate the effects of Wegener-Bergeron-Findeisen process (hereafter WBF) on black carbon (BC) scavenging efficiency, surface $\mathrm{BC}_{\mathrm{air}}$, deposition flux, concentration in snow $\left(\mathrm{BC}_{\text {snow }}, \mathrm{ngg}^{-1}\right)$, and washout ratio using a global 3-D chemical transport model (GEOS-Chem). We differentiate riming-versus WBFdominated in-cloud scavenging based on liquid water content (LWC) and temperature. Specifically, we implement an implied WBF parameterization using either temperature or ice mass fraction (IMF) in mixed-phase clouds based on field measurements. We find that at Jungfraujoch, Switzerland, and Abisko, Sweden, where WBF dominates in-cloud scavenging, including the WBF effect strongly reduces the discrepancies of simulated BC scavenging efficiency and washout ratio against observations (from a factor of 3 to $10 \%$ and from a factor of 4-5 to a factor of 2). However, at Zeppelin, Norway, where riming dominates, simulation of $\mathrm{BC}$ scavenging efficiency, $\mathrm{BC}_{\mathrm{air}}$, and washout ratio become worse (relative to observations) when WBF is included. There is thus an urgent need for extensive observations to distinguish and characterize riming- versus $\mathrm{WBF}$ dominated aerosol scavenging in mixed-phase clouds and the associated BC scavenging efficiency. Our model results show that including the WBF effect lowers global BC scavenging efficiency, with a higher reduction at higher latitudes $(8 \%$ in the tropics and up to $76 \%$ in the Arctic). The resulting annual mean $\mathrm{BC}_{\text {air }}$ increases by up to $156 \%$ at high altitudes and at northern high latitudes because of lower temperature and higher IMF. Overall, WBF halves the model-observation discrepancy (from -65 to $-30 \%$ ) of $\mathrm{BC}_{\mathrm{air}}$ across North Amer-
\end{abstract}

ica, Europe, China and the Arctic. Globally WBF increases BC burden from 0.22 to $0.29-0.35 \mathrm{mg} \mathrm{m}^{-2} \mathrm{yr}^{-1}$, which partially explains the gap between observed and previous modelsimulated BC burdens over land. In addition, WBF significantly increases BC lifetime from 5.7 to $\sim 8$ days. Additionally, WBF results in a significant redistribution of $\mathrm{BC}$ deposition in source and remote regions. Specifically, it lowers BC wet deposition (by 37-63\% at northern mid-latitudes and by $21-29 \%$ in the Arctic), while it increases dry deposition (by $3-16 \%$ at mid-latitudes and by $81-159 \%$ in the Arctic). The resulting total $\mathrm{BC}$ deposition is lower at mid-latitudes (by 12-34\%) but higher in the Arctic (by 2-29\%). We find that $\mathrm{WBF}$ decreases $\mathrm{BC}_{\text {snow }}$ at mid-latitudes (by $\sim 15 \%$ ) but increases it in the Arctic (by $26 \%$ ) while improving model comparisons with observations. In addition, WBF dramatically reduces the model-observation discrepancy of washout ratios in winter (from a factor of 16 to 4 ). The remaining discrepancies in $\mathrm{BC}_{\mathrm{air}}, \mathrm{BC}_{\text {snow }}$ and $\mathrm{BC}$ washout ratios suggest that in-cloud removal in mixed-phased clouds is likely still excessive over land.

\section{Introduction}

Black carbon (BC) effectively heats the atmosphere by absorbing solar radiation and has been regarded as the second largest warming agent after $\mathrm{CO}_{2}$ (Ramanathan and Carmichael, 2008; Bond et al., 2013; IPCC 2014). Moreover, BC deposited on snow and ice reduces surface albedo and accelerates melting (Flanner et al., 2007; He et al., 2014b; 
IPCC, 2014; Liou et al., 2014). However, there are large uncertainties in estimating direct radiative forcing of $\mathrm{BC}$, mainly arising from the uncertainties in predicting $\mathrm{BC}$ distribution (Bond et al., 2013). Current models in the project Aerosol Comparisons between Observations and Models (AeroCom) underestimate aerosol absorption optical depth (AAOD) of BC observed by the AErosol RObotic NETwork (AERONET) and satellite by a factor of 1.6-4 (Bond et al., 2013) but overestimates $\mathrm{BC}_{\text {air }}$ observed in remote Pacific by a factor of 2-5 (Schwarz et al., 2010; Q. Wang et al., 2014; X. Wang et al., 2014). Moreover, inter-model disagreement of $\mathrm{BC}$ loadings simulated by AeroCom models is up to 2 to 3 orders of magnitude (Koch et al., 2009; Bond et al., 2013). The large discrepancy with observations and large disagreement among models are primarily attributed to wet deposition, which is the dominant mechanism to remove $\mathrm{BC}$ from the atmosphere (Textor et al., 2006; Koch et al., 2009; Bond et al., 2013) and consequently determines its lifetime and atmospheric burden. The major process of wet scavenging is in-cloud scavenging (Taylor et al., 2014), which occurs in two stages: aerosol activation to form cloud droplets, and removal of droplets by precipitation. The ability of a particle to be activated as a cloud condensation nucleus (CCN) and thereby be scavenged by in-cloud scavenging depends on its hygroscopicity, size, and super-saturation in the cloud (Ghan et al., 2011). The partition of BC particles between condensed phase and interstitial air in clouds is quantified by scavenging efficiency, which is defined as the ratio of aerosol mass mixing ratio in cloud drops and ice crystals to total aerosol mass mixing ratio in clouds (including aerosols in interstitial air and in cloud drops).

The determining factors controlling $\mathrm{BC}$ scavenging efficiency in clouds are the properties of $\mathrm{BC}$ particles, including their hygroscopicity, size, and chemical composition (Sellegri et al., 2003; Hallberg et al., 1992, 1994). Local changes of updraft velocity and critical super-saturation significantly affect local BC scavenging efficiency. Such effects are also observed at long-time averages. In mixed-phase clouds, the effect of cloud microphysics on BC scavenging is considerably more complex. One complicating factor is the so-called Wegener-Bergeron-Findeisen process (hereafter WBF; Wegener, 1911; Bergeron, 1935; Findeisen, 1938), where water vapor transfers from liquid to ice phases when vapor pressure is between the saturation vapor pressure over ice and water droplets. Liquid cloud droplets evaporate and release the aerosol materials in the droplets back into interstitial air, resulting in a slower scavenging of aerosols in mixed-phase clouds. The water vapor evaporated from water drops deposit onto ice surface and snow particles form. Accordingly, WBF leads to slower $\mathrm{BC}$ scavenging and faster snow growth. Theoretical estimates show that snow growth rate from WBF is a function of temperature (Pruppacher and Klett, 2010). As temperature lowers from 0 to $-14^{\circ} \mathrm{C}$, snow growth rate is estimated to increase drastically from 0 to $5.2 \times 10^{-8}\left(\mathrm{~g} \mathrm{~s}^{-1}\right)$ at $500 \mathrm{hPa}$ (Pruppacher and Klett, 2010), and BC scaveng- ing efficiency at Jungfraujoch is observed to decrease from 0.6 to 0.2 (Cozic et al., 2007). From -14 to $-25^{\circ} \mathrm{C}$, the estimated snow growth rate from $\mathrm{WBF}$ varies in a relatively smaller range $\left(4.8-5.5 \times 10^{-8} \mathrm{~g} \mathrm{~s}^{-1}\right.$, Pruppacher and Klett, 2010), and BC scavenging efficiency varies in 0.1-0.2 (Cozic et al., 2007). The two anti-correlated trends indicate that WBF is a very important factor that explains the observed temperature dependence of $\mathrm{BC}$ scavenging efficiency at Jungfraujoch. Another process that affects $\mathrm{BC}$ scavenging in mixed-phase clouds is riming (Hegg et al., 2011). Riming occurs when LWC is high and gravitationally settling of snowflakes and ice crystals collect the water drops along their pathways, thereby scavenging BC particles in the water drops. At Zeppelin, where snow particles show predominantly rimed structures, $\mathrm{BC}$ scavenging efficiency changes marginally (within $5 \%$ ) from summer $(0.77)$ to winter $(0.81)$ as the average temperature lowers from $-2^{\circ} \mathrm{C}$ in summer to $-14^{\circ} \mathrm{C}$ in winter (Heintzenberg and Leck, 1994). The different trends of the scavenging efficiency with temperature observed at Jungfraujoch and Zeppelin indicate that WBF and riming are the major processes that determine $\mathrm{BC}$ scavenging efficiency in mixed-phase clouds. Therefore, the decreasing of $\mathrm{BC}$ scavenging efficiency with decreasing temperature at Jungfraujoch is mainly attributed to WBF (Cozic et al., 2007). Recent studies have found that this reduction of BC scavenging efficiency from WBF not only affects wet scavenging of aerosols but also strongly affects cloud feedbacks and climate sensitivities (Tan et al., 2016). Thus, it is critical to differentiate WBF and riming process in model simulations.

$\mathrm{BC}$ scavenging efficiency is typically prescribed as a constant (between 0 and 1) in global chemical transport models (CTMs) for computational efficiency consideration and the limited understanding of the processes controlling the partition of $\mathrm{BC}$ between interstitial air and condensed phases in mixed-phase clouds (Textor et al., 2006). Textor et al. (2006) and Wang et al. (2011) treated BC scavenging in mixedphase the same as in warm liquid clouds. Stier et al. (2005) used a scavenging efficiency of 0.40 for soluble Aitkenmode aerosols and 0.75 for accumulation-mode aerosols in mixed-phase clouds, lower (by 0.10) than their corresponding values in liquid-only clouds. Using the same model, Bourgeois and Bey (2011) applied a substantially lower scavenging efficiency (0.06) for both Aitken- and accumulationmode aerosols in mixed-phase clouds based on measurements from Henning et al. (2004). The lower scavenging efficiency results in 5-fold higher BC burden in the Arctic (from 0.75 to $3.7 \mathrm{Gg}$ ) and 3-fold longer $\mathrm{BC}$ lifetime (from 1.8 to 5.8 days). Liu et al. (2011) and Browse et al. (2012) also showed that BC loading and lifetime are both very sensitive to scavenging efficiency. It is clear that a systematic examination of BC scavenging efficiency and wet deposition is warranted. To that end, recent comprehensive largescale measurements of $\mathrm{BC}_{\text {snow }}$ in North America (Doherty et al., 2014), China (Huang et al., 2011; Ye et al., 2012; 
X. Wang et al., 2013, 2014; Zhang et al., 2013), and the Arctic (Doherty et al., 2010) provide a unique opportunity. Concurrent measurements of $\mathrm{BC}$ in fresh snow and rain $\left(\mathrm{BC}_{\text {snow/rain }}\right)$ and $\mathrm{BC}_{\text {air }}$ (Cerqueira et al., 2010; Mori et al., 2014) provide better constraints on $\mathrm{BC}$ wet deposition.

$\mathrm{BC}$ scavenging efficiency varies as a function of $\mathrm{BC}$ aging in GEOS-Chem (Park et al., 2005; Wang et al., 2011). Specifically, in warm and mixed-phase clouds, hydrophilic BC particles are completely (100\%) incorporated in cloud drops and serve as $\mathrm{CCN}$, while hydrophobic $\mathrm{BC}$ particles remain in interstitial air. In ice clouds, hydrophobic BC particles serve as ice condensation nuclei, while hydrophilic BC particles are not scavenged. In this study we investigate the effect of WBF on $\mathrm{BC}$ scavenging, its distribution in air and snow, and the budget using GEOS-Chem. Specifically, we distinguish riming- versus WBF-dominated in-cloud scavenging in mixed-phase clouds and parameterize BC scavenging efficiency accordingly. We evaluate model results of $\mathrm{BC}$ scavenging efficiency (Sect. 4.1), $\mathrm{BC}_{\mathrm{air}}$ (Sect. 4.2), BC wet deposition fluxes (Sect. 4.3), $\mathrm{BC}_{\text {snow }}$ (Sect. 4.4), and $\mathrm{BC}$ washout ratio (Sect. 4.5). We further discuss the WBF effects on global BC budget (Sect. 5), followed by conclusions and implications (Sect. 6).

\section{Observations}

Figure 1 shows sites with measurements of $\mathrm{BC}$ scavenging efficiency, $\mathrm{BC}_{\mathrm{air}}, \mathrm{BC}_{\mathrm{snow}}$, and $\mathrm{BC}$ washout ratio in the Northern Hemisphere.

\subsection{Scavenging efficiency measurements}

$\mathrm{BC}$ scavenging efficiencies in mixed-phase clouds are not well understood. In mixed-phase clouds, BC is partitioned between condensed phase (water drops and ice crystals) and interstitial air, which is crucial for accurate estimates of the in-cloud scavenging of BC. Following Hallberg et al. (1992) and references thereafter, the scavenging efficiency is defined as

$r_{\text {scav. }}=\frac{[\mathrm{BC}]_{\text {condensed }}}{[\mathrm{BC}]_{\text {interstitial }}+[\mathrm{BC}]_{\text {condensed }}}$,

where $r_{\text {scav. }}$ is $\mathrm{BC}$ scavenging efficiency, $[\mathrm{BC}]_{\text {condensed }}$ the mass mixing ratio of $\mathrm{BC}$ in condensed phase, and $[\mathrm{BC}]_{\text {interstitial }}$ the mass mixing ratio of $\mathrm{BC}$ in the interstitial air.

There are eight surface sites that reported measurements of BC scavenging efficiencies (Table 1 and Fig. 1). Cloud droplets and interstitial air were collected through different inlets. Cloud droplets were collected by a counterflow virtual impactor (CVI) (Ogren et al., 1985). Interstitial air was sampled by impactor-type collectors such as annular-slit impactor, round jet impactor, and mini-cascade impactor. Field calibration of the two inlets as well as theoretical consideration and laboratory calibration showed that the overall un-

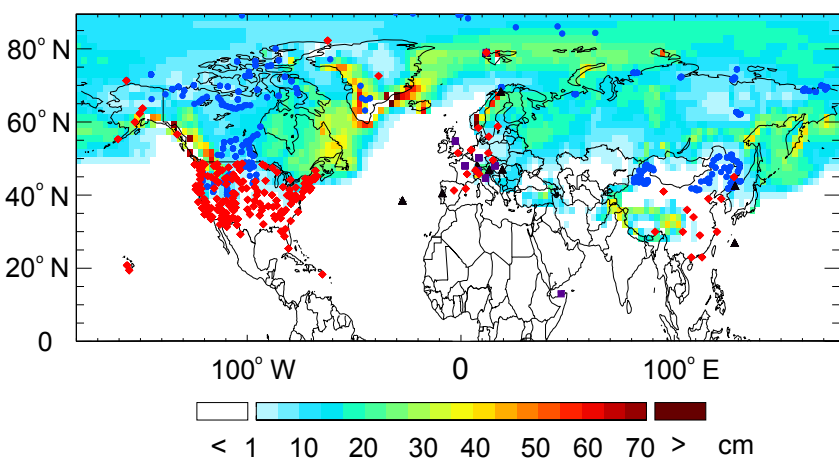

Figure 1. BC measurements used in this study: scavenging efficiencies (purple squares), concentration in air (red diamonds), concentration in snow (blue circles), washout ratio (black triangles), and average snow depth $(\mathrm{cm})$ for 2006-2012 (color contours).

certainty of mass concentration of particles of the two phases in clouds was close to $15 \%$ (Sellegri et al., 2003). The scavenged fraction was then computed from the comparison between cloud impactor samples and interstitial aerosols (e.g., Hallberg et al., 1992, 1994; Heintzenberg and Leck, 1994; Gieray et al., 1997; Hitzenberger et al., 2000, 2001). Longterm measurements of $\mathrm{BC}$ mass mixing ratios in clouds require that the in situ sites are located at high altitudes with frequent clouds. Only a few sites meet these requirements. Thus, available measurements of $\mathrm{BC}$ scavenging efficiencies are very limited.

The observed BC scavenging efficiencies increase with increasing distance from source regions, from 0.06 in heavily polluted fog in Po Valley, Italy $\left(44.6^{\circ} \mathrm{N}, 11.6^{\circ} \mathrm{E}\right.$; sea level), (Hallberg et al., 1992) to 0.81 at Zepplin $\left(79^{\circ} \mathrm{N}, 12^{\circ} \mathrm{E}\right.$; $0.47 \mathrm{~km}$ ) in the Arctic (Heintzenberg and Leck, 1994) (Table 1). The observed scavenging efficiencies were vastly different at the Po Valley: 0.06 from Hallberg et al. (1992) and 0.39 from Gilardoni et al. (2014). Reasons for the difference are unclear. Freshly emitted BC particles are mostly hydrophobic and cannot serve as CCN (Weingartner et al., 1997). Hydrophobic BC particles mix with hydrophilic materials (e.g., sulfate, nitrate or soluble organics) during transit and become hydrophilic and larger in size (Sellegri et al., 2003). The incorporation of BC particles into cloud droplets via nucleation scavenging is thus enhanced (Moteki et al., 2012; Taylor et al., 2014). Both cloud dynamics (e.g., updraft velocity) and microphysics (nucleation, condensation and coagulation) complicate and determine the partition of $\mathrm{BC}$ particles between condensed phase and interstitial air in mixed-phase clouds (Cozic et al., 2007). When riming occurs, large snow crystals collect cloud water drops along their pathways and BC particles in these cloud water drops are likewise removed (Heintzenberg and Leck, 1994; Hegg et al., 2011). BC scavenging efficiency due to riming is thus similar to that in warm clouds. For example, at Zeppelin, where the riming process was typically dominant, 
Table 1. Observed and GEOS-Chem-simulated scavenging efficiency of BC (fraction of BC incorporated into cloud droplets and ice crystals).

\begin{tabular}{|c|c|c|c|c|c|c|}
\hline \multirow[t]{2}{*}{ Site } & \multirow[t]{2}{*}{ Observations } & \multicolumn{3}{|c|}{ Model } & \multirow[t]{2}{*}{ Time } & \multirow[t]{2}{*}{ References } \\
\hline & & Riming-only $^{\mathrm{a}}$ & $\mathrm{WBF}_{\mathrm{T}} \mathrm{b}$ & $\mathrm{WBF}_{\mathrm{IMF}}{ }^{\mathrm{c}}$ & & \\
\hline $\begin{array}{l}\text { Jungfraujoch } \\
\left(46.5^{\circ} \mathrm{N}, 8^{\circ} \mathrm{E}, 3.85 \mathrm{~km}\right)\end{array}$ & 0.60 & 0.90 & 0.59 & 0.48 & Jul-Aug 2004 & Cozic et al. (2007) \\
\hline Jungfraujoch & $0.05-0.10$ & 0.29 & 0.11 & 0.10 & Feb-Mar 2004 & Cozic et al. (2007) \\
\hline $\begin{array}{l}\text { Puy de Dôme } \\
\left(48^{\circ} \mathrm{N}, 2^{\circ} \mathrm{E}, 1.46 \mathrm{~km}\right)\end{array}$ & $0.43 \pm 0.17$ & 0.71 & 0.63 & 0.48 & Feb-Mar 2001 & Sellegri et al. (2003) \\
\hline $\begin{array}{l}\text { Zeppelin } \\
\left(79^{\circ} \mathrm{N}, 12^{\circ} \mathrm{E}, 0.47 \mathrm{~km}\right)\end{array}$ & 0.81 & 0.89 & 0.53 & 0.14 & May-Oct 1990-1992 & Heintzenberg and Leck (1994) \\
\hline Zeppelin & 0.77 & 0.41 & 0.11 & 0.03 & Oct-May 1990-1992 & Heintzenberg and Leck (1994) \\
\hline $\begin{array}{l}\text { Mt. Sonnblick } \\
\left(47^{\circ} \mathrm{N}, 13.4^{\circ} \mathrm{E}, 3.11 \mathrm{~km}\right)\end{array}$ & $0.74 \pm 0.19$ & 0.67 & 0.26 & 0.10 & Apr-May 1997 & Hitzenberger et al. (2000) \\
\hline $\begin{array}{l}\text { Po Valley } \\
\left(44.6^{\circ} \mathrm{N}, 11.6^{\circ} \mathrm{E}, 0 \mathrm{~km}\right)\end{array}$ & $0.06(0.01-0.30)$ & - & - & - & Nov 1989 & Hallberg et al. (1992) \\
\hline Po Valley ${ }^{\mathrm{d}}$ & $0.39(0.31-0.57)$ & 0.55 & 0.53 & 0.46 & Nov 2011 & Gilardoni et al. (2014) \\
\hline $\begin{array}{l}\text { Great Dun Fell } \\
\left(54.7^{\circ} \mathrm{N}, 2.5^{\circ} \mathrm{W}, 0.85 \mathrm{~km}\right)\end{array}$ & $0.50 \pm 0.20$ & 0.61 & 0.59 & 0.46 & Apr-May 1993 & Gieray et al. (1997) \\
\hline $\begin{array}{l}\operatorname{Rax} \\
\left(48^{\circ} \mathrm{N}, 16^{\circ} \mathrm{E}, 1.64 \mathrm{~km}\right)\end{array}$ & $0.54 \pm 0.25$ & 0.70 & 0.64 & 0.35 & Mar 1999-Apr 2000 & Hitzenberger et al. (2001) \\
\hline
\end{tabular}

${ }^{a}$ Simulation with riming only in-cloud scavenging of $\mathrm{BC}$ in mixed-phase clouds. See text for details. ${ }^{\mathrm{b}}$ Simulation with in-cloud scavenging of BC by WBF, parameterized by temperature, in mixed-phase clouds. See text for details. ${ }^{\mathrm{c}}$ Simulation with in-cloud scavenging of BC by WBF, parameterized by ice mass fraction, in mixed-phase clouds. See text for details. ${ }^{\mathrm{d}}$ Observations in urban fog.

BC scavenging efficiencies in winter (0.77) (mostly mixedphase clouds and ice clouds) and in summer (0.81) (mostly warm liquid clouds) were within $5 \%$ (Heintzenberg and Leck, 1994). In contrast, when the WBF process occurs, ice crystals grow at the expense of water droplets and hence BC particles inside the water droplets are released back into the interstitial air, thereby lowering in-cloud $\mathrm{BC}$ scavenging efficiency. The scavenging efficiency at Jungfraujoch $\left(46.5^{\circ} \mathrm{N}\right.$, $8^{\circ} \mathrm{E} ; 3.85 \mathrm{~km}$ ), where the WBF process dominates in mixedphase clouds, was higher in warm clouds (0.6) in summer and substantially lower in mixed-phase clouds $(0.05-0.10)$ in spring (Cozic et al., 2007).

Cozic et al. (2007) reported comprehensive observations of BC scavenging efficiency at Jungfraujoch, a site regularly engulfed by clouds ( $30 \%$ of the time) and far away from pollution sources. The site is well suited for investigating continental background aerosols and clouds from a ground-based platform. Cozic et al. (2007) examined the partitioning of $\mathrm{BC}$ in mixed-phase clouds by sampling through two inlets, with one heated inlet collecting aerosols in cloud drops, ice crystals and the interstitial air and the other collecting only aerosols in the interstitial air. They found that the scavenging efficiency of $\mathrm{BC}$ was influenced by LWC, BC content, temperature and IMF. We use their results to parameterize the effect of WBF on BC scavenging efficiency in this study (See Sect. 3).

\subsection{BC in surface air}

Surface $\mathrm{BC}_{\text {air }}$ has been widely measured across the Arctic, North America, Europe and Asia (Fig. 1). Observations in the Arctic are available at Denali, Alaska; Barrow, Alaska; Alert, Canada; Zeppelin, Norway; and Summit, Greenland (see details in Qi et al., 2017). We also use here measurements of $\mathrm{BC}_{\text {air }}$ at 178 sites as part of the Interagency Monitoring of PROtected Visual Environment (IMPROVE; Malm et al., 1994; http://vista.cira.colostate.edu/improve/) network in North America. IMPROVE measurements were made every 3 days and $24 \mathrm{~h}$ averages were reported. Additionally, we use $\mathrm{BC}_{\text {air }}$ observations from East Asia in 2006 (X. Y. Zhang et al., 2008). Observations of $\mathrm{BC}_{\mathrm{air}}$ in Europe are from the European Monitoring and Evaluation Programme (EMEP) network (EMEP/MSC-W et al., 2014; http://ebas.nilu.no). We use here daily EMEP measurements.

The thermal optical reflectance (TOR) combustion method is used to measure BC concentrations by IMPROVE and EMEP network based on the preferential oxidation of organic carbon (OC) and elemental carbon (EC) at different temperatures (Chow et al., 1993, 2004). Heating protocols used by IMPROVE network are as follows: the sample filter is heated stepwise at temperatures of $120^{\circ} \mathrm{C}(\mathrm{OC} 1), 250^{\circ} \mathrm{C}$ (OC2), $450^{\circ} \mathrm{C}(\mathrm{OC} 3)$, and $550^{\circ} \mathrm{C}(\mathrm{OC} 4)$ in a non-oxidizing (He) atmosphere, and at $550^{\circ} \mathrm{C}(\mathrm{EC} 1), 700^{\circ} \mathrm{C}(\mathrm{EC} 2)$, and $800^{\circ} \mathrm{C}(\mathrm{EC} 3)$ in an oxidizing atmosphere of $2 \%$ oxygen and 
$98 \% \mathrm{He}$. Evolved carbon is oxidized to $\mathrm{CO}_{2}$ and then reduced to $\mathrm{CH}_{4}$ for detection. The pyrolyzed or charred OC is monitored by reflectance at wavelength $\lambda=633 \mathrm{~nm}$. The portion of EC1 until the laser signal returns to its initial value is assigned to pyrolyzed organic carbon (OP). $\mathrm{EC}$ is defined by $\mathrm{EC} 1+\mathrm{EC} 2+\mathrm{EC} 3-\mathrm{OP}$. We use EC here to approximate the concentration of BC. EMEP use different protocols. Samples were heated up to either $850^{\circ} \mathrm{C}(\mathrm{NIOSH})$ (and hence a fraction of EC may be combusted) or $650^{\circ} \mathrm{C}$ (EUSAAR_2; EUROPA, 2008). BC-like products of OC pyrolysis can lead to uncertainty in measuring $\mathrm{BC}$ mass. The uncertainty is estimated to be $\sim 20 \%$ based on the repeatability and reproducibility of the measurements (EMEP/MSC-W et al., 2014).

\subsection{BC in snow}

We use $\mathrm{BC}_{\text {snow }}\left(\mathrm{ngg}^{-1}\right)$ to constrain $\mathrm{BC}$ deposition on snow-covered surfaces. There is now a comprehensive set of $\mathrm{BC}_{\text {snow }}$ measurements, from sampling the full snowpack depth, in the Northern Hemisphere (Fig. 1): the Arctic (Doherty et al., 2010), North America (Doherty et al., 2014), northern China (Wang et al., 2013), and Xinjiang, China (Ye et al., 2012). For direct comparison with model results, we merge the observations in the same model grid cell. We exclude samples with obvious contamination from dust, soil, or local emissions as indicated in the observations. This leaves out a sample number of 334 from the Arctic, 158 from North America, 97 from northern China, and 47 from Xinjiang, China. Doherty et al. (2014) grouped samples in North America into four geographic regions based on land surface type and seasonal average snow water equivalent: Canada, the Great Plains, the Pacific Northwest, and the Intra-Mountain Northwest. Here we follow the same definitions. Wang et al. (2013) defined three subregions of northern China: Inner Mongolia, Northeast Border, and Northeast Industrial. We use the same definitions in this study. The largest uncertainties of these measurements are uncertainties of $\mathrm{BC}$ mass absorption cross section (-25\%), $\mathrm{BC}$ and non$\mathrm{BC}$ absorption Ångström exponent used to estimate $\mathrm{BC}_{\text {snow }}$ ( $\sim 50 \%$, Doherty et al., 2010). Other uncertainties include instrumental uncertainty $(\leq 11 \%)$ and under-catch correction $( \pm 15 \%)$ (see details in Doherty et al., 2010). The resulting overall uncertainty of the observed $\mathrm{BC}_{\text {snow }}$ is $<60 \%$.

\subsection{Washout ratio measurements}

Washout ratio is a more easily measured parameter (compared to scavenging efficiency) that characterizes wet scavenging of $\mathrm{BC}$. It is defined as the ratio of $\mathrm{BC}$ mass mixing ratio in fresh rain and snow to that in surface air following Hegg et al. (2011),

$r_{\text {washout }}=\frac{[\mathrm{BC}]_{\mathrm{rain} / \mathrm{snow}}}{[\mathrm{BC}]_{\mathrm{air}}}$,

where $r_{\text {washout }}$ is the washout ratio, $[\mathrm{BC}]_{\text {rain/snow }}$ the $\mathrm{BC}$ mass mixing ratio in fresh rain or snow, and $[\mathrm{BC}]_{\text {air }}$ the $\mathrm{BC}$ mass mixing ratio in surface air. Washout ratio is an ambiguous metric for scavenging because it is rare that surface $\mathrm{BC}_{\mathrm{air}}$ is representative of that at the altitude where $\mathrm{BC}$ aerosols are scavenged. On the other hand, washout ratio does subsume a number of individual processes such as in-cloud scavenging and below-cloud scavenging to give an estimate of an overall assignment (Hegg et al., 2011). Thus, unlike BC scavenging efficiency, which quantitatively describes the partition of BC in condensed phase and interstitial air in clouds, BC washout ratio is only a qualitative index for scavenging, which might partly explain why we have such limited observations of washout ratios so far. During snow season, washout ratio characterizes the riming- versus WBF-dominated snow formation process and $\mathrm{BC}$ scavenging in mixed-phase clouds. The washout ratio at Zeppelin, where snow particles show rimed structures, shows that $\mathrm{BC}$ particles are scavenged efficiently and the scavenging efficiency was $\sim 770$ (Hegg et al., 2011). However, at Abisko and Changbai, where pristine crystal snow particles formed mainly from the WBF effect, $\mathrm{BC}$ was scavenged much less efficiently than that in rimingdominated condition, resulting in a much smaller washout ratio ( 150; Noone and Clark, 1988; Z. W. Wang et al., 2014). This is because BC particles in cloud drops were released back to the interstitial air and not subject to scavenging.

Figure 1 shows nine remote sites with concurrent measurements of $\mathrm{BC}_{\text {rain/snow }}$ and $\mathrm{BC}_{\text {air }}$ to estimate washout ratio (black triangles in Fig. 1). $\mathrm{BC}_{\text {air }}$ and $\mathrm{BC}_{\text {rain/snow }}$ were measured at Cape Hedo $\left(26.9^{\circ} \mathrm{N}, 128.3^{\circ} \mathrm{E}, 0.06 \mathrm{~m}\right)$ in the East China Sea during 2011-2013. BC $\mathrm{B}_{\text {air }}$ was measured with an integration time of $1 \mathrm{~min}$ using a filter-based absorption photometer. The accuracy of this measurement has been estimated to be about $10 \%$ based on the consistency of the measured $\mathrm{BC}$ concentration by three methods, including a filter-based absorption photometer, thermal-optical transmittance method and single-particle soot photometer (Mori et al., 2014; Kondo et al., 2011). $\mathrm{BC}_{\text {rain/snow }}$ was measured with a system based on an ultrasonic nebulizer, with an overall accuracy of about $25 \%$ (Mori et al., 2014). $\mathrm{BC}_{\text {air }}$ and $\mathrm{BC}_{\text {rain/snow }}$ were measured concurrently in Europe at two rural background sites - Aveiro $\left(40.5^{\circ} \mathrm{N}, 8.6^{\circ} \mathrm{W}, 0.05 \mathrm{~km}\right)$ and K-puszta, Hungary $\left(47^{\circ} \mathrm{N}, 19.5^{\circ} \mathrm{E}, 0.2 \mathrm{~km}\right)$ - and two mountain sites, Schauinsland, German $\left(47.9^{\circ} \mathrm{N}, 7.9^{\circ} \mathrm{E}, 1.2 \mathrm{~km}\right)$ and Sonnblick, Austria $\left(47^{\circ} \mathrm{N}, 13.4^{\circ} \mathrm{E}, 3.1 \mathrm{~km}\right)$ in $2002-$ 2004 (Cerqueira et al., 2010). Sampling of rain and snow mainly focused on major precipitation events in order to collect large volumes over short-time periods. Samples were collected on an event basis with a stainless steel funnel connected to a pre-cleaned glass bottle. In order to minimize dry deposition of particles, the collector was deployed when rain started to fall and was removed immediately after filling or at the end of the event. $\mathrm{BC}_{\text {rain/snow }}$ was measured using the thermal-optical method described by Castro et al. (1999). Weekly air samples corresponding to the precipitation period were taken and $\mathrm{BC}_{\text {air }}$ was determined by thermal-optical method with the NIOSH protocol (Pio et al., 2007). 
Table 2. Observed and GEOS-Chem-simulated BC concentration in snow and rain $\left(\mu \mathrm{L}^{-1}\right), \mathrm{BC}$ concentration in surface air $\left(\mu \mathrm{g} \mathrm{m}^{-3}\right)$ and the corresponding washout ratio.

\begin{tabular}{|c|c|c|c|c|c|c|}
\hline \multirow[t]{2}{*}{ Site } & & \multicolumn{2}{|c|}{ BC concentration } & \multirow[t]{2}{*}{ Washout ratio } & \multirow[t]{2}{*}{ Time } & \multirow[t]{2}{*}{ Reference } \\
\hline & & $\begin{array}{l}\text { Snow or rain } \\
\qquad\left(\mu \mathrm{gL}^{-1}\right)\end{array}$ & $\begin{array}{r}\text { Surface air } \\
\left(\mu \mathrm{g} \mathrm{m}^{-3}\right)\end{array}$ & & & \\
\hline \multirow{4}{*}{$\begin{array}{l}\text { Changbai } \\
\left(42.5^{\circ} \mathrm{N}\right. \\
128.5^{\circ} \mathrm{E} \\
0.74 \mathrm{~km})\end{array}$} & Observations & & & 145 & \multirow{4}{*}{$\begin{array}{l}\text { Nov-Dec, } \\
\text { Mar 2009-2012 }\end{array}$} & \multirow{4}{*}{ Wang et al. (2012) } \\
\hline & Riming-only ${ }^{\mathrm{a}}$ & 281 & 0.574 & 501 & & \\
\hline & $\mathrm{WBF}_{\mathrm{T}} \mathrm{b}$ & 232 & 0.603 & 403 & & \\
\hline & $\mathrm{WBF}_{\mathrm{IMF}}{ }^{\mathrm{c}}$ & 178 & 0.643 & 336 & & \\
\hline \multirow{4}{*}{$\begin{array}{l}\text { LAVO } \\
\left(40.5^{\circ} \mathrm{N}\right. \\
121^{\circ} \mathrm{W} \\
1.73 \mathrm{~km})\end{array}$} & Observations & 4.2 & 0.024 & 229 & \multirow{4}{*}{ Mar 2006} & \multirow{4}{*}{ Hadley et al. (2010) } \\
\hline & Riming-only & 13.7 & 0.021 & 719 & & \\
\hline & $\mathrm{WBF}_{\mathrm{T}}$ & 18.7 & 0.034 & 523 & & \\
\hline & $\mathrm{WBF}_{\mathrm{IMF}}$ & 18.3 & 0.048 & 400 & & \\
\hline \multirow{4}{*}{$\begin{array}{l}\text { Abisko } \\
\left(68.3^{\circ} \mathrm{N}\right. \\
18.8^{\circ} \mathrm{E} \\
0.35 \mathrm{~km})\end{array}$} & Observations & $2.4-77.1$ & $0.03-0.93$ & 94 & \multirow{4}{*}{ Mar-Apr 1984} & \multirow{4}{*}{ Noone and Clark (1988) } \\
\hline & Riming-only & 13.3 & 0.031 & 482 & & \\
\hline & $\mathrm{WBF}_{\mathrm{T}}$ & 10.0 & 0.051 & 203 & & \\
\hline & $\mathrm{WBF}_{\mathrm{IMF}}$ & 7.5 & 0.072 & 96 & & \\
\hline Zeppelin & Observations & 13.9 & 0.030 & 769 & \multirow{4}{*}{ Mar-Apr 2007} & \multirow{4}{*}{ Hegg et al. (2011) } \\
\hline$\left(79.0^{\circ} \mathrm{N}\right.$ & Riming-only & 6.1 & 0.019 & 444 & & \\
\hline $12.0^{\circ} \mathrm{E}$ & $\mathrm{WBF}_{\mathrm{T}}$ & 4.9 & 0.041 & 109 & & \\
\hline 0.47 km) & $\mathrm{WBF}_{\mathrm{IMF}}$ & 4.4 & 0.063 & 62 & & \\
\hline
\end{tabular}

${ }^{a}$ Simulation with riming only in-cloud scavenging of BC in mixed-phase clouds. See text for details. ${ }^{b}$ Simulation with in-cloud scavenging of BC by WBF, parameterized by temperature, in mixed-phase clouds. See text for details. ${ }^{c}$ Simulation with in-cloud scavenging of BC by WBF, parameterized by ice mass fraction, in mixed-phase clouds. See text for details.

At site Changbai, China $\left(42.5^{\circ} \mathrm{N}, 128.5^{\circ} \mathrm{E} ; 0.74 \mathrm{~km}\right)$; LAVO, California $\left(40.5^{\circ} \mathrm{N}, 121^{\circ} \mathrm{W} ; 1.73 \mathrm{~km}\right)$; Abisko, Sweden $\left(68.3^{\circ} \mathrm{N}, 18.8^{\circ} \mathrm{E} ; 0.35 \mathrm{~km}\right)$; and Zeppelin, Norway $\left(79.0^{\circ} \mathrm{N}, 12.0^{\circ} \mathrm{E} ; 0.47 \mathrm{~km}\right)$, observations were taken only in spring or winter (Table 2). At Changbai, snow samples were collected once per week during three winters in

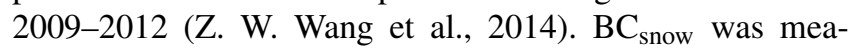
sured using the thermal-optical method with IMPROVE protocol and $\mathrm{BC}_{\text {air }}$ was determined using a particle soot absorption photometer (PSAP). At LAVO, seven precipitation samples were collected in March 2006 using an automated rain sampler EcoTech with up to $95 \%$ capture efficiency

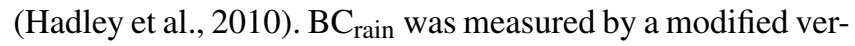
sion of thermo-optical analysis described in detail in Hadley et al. (2008). $\mathrm{BC}_{\text {air }}$ was measured by seven-wavelength Aethalometer with an overall uncertainty of about $\pm 30 \%$.

At Abisko, snow samples were taken in March and April in 1984 (Noone and Clark, 1988). Snow samples were taken using a plastic spatula to scrape fresh snow into polyethylene jars and then transported back to the laboratory. The snow was transferred to a filtration apparatus, where it was melted and filtered. The amount of BC on the filters was determined by optical analysis. The air samples were measured using the integrating sandwich technique. At Zeppelin, $\mathrm{BC}_{\text {snow }}$ and $\mathrm{BC}_{\text {air }}$ were measured concurrently in April and May 2007. BC $_{\text {snow }}$ was concentrated by Nuclepore filters and then determined using a multiwavelength spectrophotometer.
Aerosol absorption is measured by PSAP and $\mathrm{BC}_{\text {air }}$ is computed using a mass absorption cross section of $11 \mathrm{~m}^{2} \mathrm{~g}^{-1}$ at $550 \mathrm{~nm}$ (Hegg et al., 2011).

\section{Model description and simulations}

\subsection{Model description}

GEOS-Chem is a 3-D global chemical transport model driven with assimilated meteorology from the Goddard Earth Observing System (GEOS) of the NASA Global Modeling and Assimilation Office (GMAO). The GEOS-5 reanalysis meteorological dataset is used to drive model simulations at $2^{\circ}$ latitude $\times 2.5^{\circ}$ longitude horizontal resolution with 47 vertical layers. BC aerosols are emitted by incomplete combustion of fossil fuel, biofuel and biomass. Global anthropogenic emissions from Bond et al. (2007) are used with Asian emissions from Zhang et al. (2009). Previously missed gas flaring emissions are also included in this study (Stohl et al., 2013; the flaring emission inventory is available at http://eclipse.nilu.no/). Biomass burning emissions are from GFED3 emission inventory, with a small fire contribution included (Randerson et al., 2012). About $80 \%$ of the freshly emitted BC aerosols are assumed to be hydrophobic (Park et al., 2003) and are converted to hydrophilic with an $e$-folding time of 1.15 days, which yields a good simulation of BC 
export efficiency in continental outflow (Park et al., 2005). Dry deposition of $\mathrm{BC}$ is computed using a resistance-inseries method over all surface types (Wesely, 1989; Zhang et al., 2001). Due to the lack of land surface module in GEOSChem, we approximate $\mathrm{BC}_{\text {snow }}$ using $\mathrm{BC}$ deposition flux and snow precipitation rate, following He et al. (2014a). More details are provided in Qi et al. (2017).

\subsection{Wet scavenging}

Aerosol wet deposition in GEOS-Chem was first described by Liu et al. (2001). It includes in-cloud and below-cloud scavenging in large-scale and convective precipitation. Incloud scavenging rate is parameterized following Giorgi and Chameides (1986),

$\phi=-\lambda[\mathrm{BC}]_{\text {condensed }}$

where $\phi$ is in-cloud scavenging rate, $\lambda$ the removal frequency determined by precipitation forming rate, and $[\mathrm{BC}]_{\text {condensed }}$ $\mathrm{BC}$ mass mixing ratio in condensed phase, including cloud water drops and ice crystals. $[\mathrm{BC}]_{\text {condensed }}$ is estimated as

$[\mathrm{BC}]_{\mathrm{condensed}}=[\mathrm{BC}]_{\mathrm{total}} \cdot r_{\mathrm{scav}}$,

where $[\mathrm{BC}]_{\text {total }}$ is $\mathrm{BC}$ mass mixing ratio in clouds, including $\mathrm{BC}$ in interstitial air and in condensed phase, and $r_{\text {scav. }}$. the BC scavenging efficiency. In GEOS-Chem, it is assumed that hydrophilic BC particles are $100 \%$ incorporated in condensed phases, while hydrophobic BC particles remain in interstitial air in warm liquid clouds (Wang et al., 2011). $r_{\text {scav }}$ is thus the fraction of hydrophilic to total BC, which is determined by the initial fraction when aerosols are emitted and the following aging process during transport. In ice clouds, hydrophobic BC can serve as ice nuclei (Andreae and Rosenfeld, 2008), and the resulting $r_{\text {scav }}$ is the fraction of hydrophobic BC to total BC.

In convective mixed-phase clouds, rapid updrafts bring water vapor to the middle and upper parts of the clouds and the resulting environmental vapor pressure is usually above the saturation vapor pressure of water. In this condition, both water and ice grow and the WBF process is suppressed (Liu et al., 2011). We assume no WBF effect in convective mixed-phase clouds. In large-scale mixed-phase clouds, cloud microphysics, which determines the rates of riming versus $\mathrm{WBF}$, play a very important role in determining $\mathrm{BC}$ scavenging efficiency. If the riming rate is much larger than WBF rate (riming-dominated), most snow particles are formed from riming and show rimed structures. $\mathrm{BC}$ particles in water drops are removed efficiently from the atmosphere. In contrast, if the rate of WBF is much larger than riming rate (WBF-dominated), most snow particles are formed from $\mathrm{WBF}$ and show pure crystal structure. BC particles in cold water drops are released back into the interstitial air and their removal is strongly slowed down. In the control experiment, riming-only (default configuration of GEOS-Chem), it is assumed that all snow particles are formed by riming process in mixed-phase clouds, and $r_{\text {scav. }}$ is treated the same as that in warm liquid clouds, which is determined solely by the hygroscopicity of BC (Table 4). In experiments $\mathrm{WBF}_{\mathrm{T}}$ and $\mathrm{WBF}_{\mathrm{IMF}}$, we distinguish riming- versus WBF-dominated conditions and parameterize $r_{\text {scav. }}$ under these two conditions. Following Fukuta and Takahashi (1999), we assume riming dominates the in-cloud scavenging in large-scale mixed-phase clouds when temperature is between 261 and $265 \mathrm{~K}$ and $\mathrm{LWC}>1.0 \mathrm{~g} \mathrm{~m}^{-3}$ because the terminal velocity of snow particles was largest at $263 \mathrm{~K}$ and large LWC provided more water drops for the falling snow particles to collect along their pathways based on lab experiments. In this condition, hydrophilic BC particles in water drops are brought to the surface by the rimed snow particles and removed from the atmosphere, so the scavenging efficiency is simply the fraction of hydrophilic to total BC. We assume that WBF dominates under other conditions (258261 and 265-273 K) in large-scale mixed-phase clouds and $r_{\text {scav. }}$ follows observations from Cozic et al. (2007). In experiment $\mathrm{WBF}_{\mathrm{T}}, r_{\text {scav }}$. is exponentially related to temperature (Table 4, Cozic et al. 2007).

$r_{\text {scav. }}=0.03+\frac{0.66}{1+\frac{\exp (-T+9.32)}{6.77}}$

In experiment $\mathrm{WBF}_{\mathrm{IMF}}, r_{\text {scav }}$ is computed using IMF (Table 4; Cozic et al., 2007).

$r_{\text {scav. }}=0.05+0.92 \cdot \exp (-8.95 \sqrt{\mathrm{IMF}})$

Although the above two parameterizations of the WBF effect include the determining factors of WBF rate, other variables that strongly affect the local WBF rate are missing, such as local updraft velocity, local vapor pressure, and distribution of cold water drops and ice crystals in mixed-phase clouds. In a follow-up study, we couple a cloud-resolving model with detailed cloud microphysics to GEOS-Chem to estimate the rate of $\mathrm{WBF}$ and riming and to further investigate their roles in determining global $\mathrm{BC}$ distribution.

\section{Results and discussions}

The primary goal of this study is to assess the impact of WBF on global BC distribution. In this section, we compare $\mathrm{BC}$ distribution from GEOS-Chem with and without WBF (Sect. 3.2). The differences can then be attributed to the WBF effect. We present the comparison of BC scavenging efficiency in Sect. 4.1. In Sect. 4.2, we show how WBF affects $\mathrm{BC}_{\text {air }}$. Following this, we present the comparison of $\mathrm{BC}$ wet deposition fluxes (Sect. 4.3) and $\mathrm{BC}_{\text {snow }}$ (Sect. 4.4). Finally, we show the effect of WBF on the $\mathrm{BC}$ washout ratio. 


\subsection{BC scavenging efficiency}

\subsubsection{Comparison to observations}

WBF improves the simulation of BC scavenging efficiency at sites where mixed-phase clouds are frequent and WBF dominates in-cloud scavenging, for example Jungfraujoch and Puy de Dôme (Cozic et al., 2007) (Table 1). At Jungfraujoch, WBF reduces $\mathrm{BC}$ scavenging efficiency both in summer (July-August, from 0.90 to $0.48-0.59$ ) and in late winter and early spring (February-March, from 0.29 to $0.10-0.11$ ) and significantly reduces model-observation discrepancies (50 to $-20-0 \%$ in summer and from a factor of 3 to $10 \%$ in late winter and early spring). At Puy de Dôme, WBF brings the simulated $\mathrm{BC}$ scavenging efficiency $\left(0.48\right.$ for $\mathrm{WBF}_{\mathrm{IMF}}$ and 0.63 for $\mathrm{WBF}_{\mathrm{T}}$ ) within the uncertainty range of observations $(0.43 \pm 0.17)$.

However, at sites where riming dominates in-cloud scavenging in mixed-phase clouds, for instance Zeppelin (Hegg et al., 2011), accounting for WBF leads to scavenging efficiencies considerably lower than observations (Table 1). Rimingonly reproduces the observed high scavenging efficiencies (0.81 in summer and 0.77 in winter) at Zeppelin to within $50 \%$. Similarly, at Mt. Sonnblick, an elevated site $(3.10 \mathrm{~km})$, the simulated scavenging efficiency with riming-only $(0.67)$ agrees with the observed values $(0.74 \pm 0.19)$ within $10 \%$ in April and May. WBF strongly reduces BC scavenging efficiency (0.09-0.26) at the site.

At lower altitudes, where temperature is higher and mixedphase clouds are less frequent, WBF has a relatively weak effect, for example, at the Po Valley and Great Dun Fell (Table 1). At the Po Valley, the measurements were in fog. We use BC scavenging efficiency of the lowest clouds in GEOSChem for comparison. All three model results - riming-only, $\mathrm{WBF}_{\mathrm{T}}$, and $\mathrm{WBF}_{\mathrm{IMF}}$ - agree with the observations (0.39) to within $20-60 \%$. At Great Dun Fell, WBF reduces BC scavenging efficiency by less than $25 \%$.

To sum up, differentiating riming- versus WBF-dominated in-cloud scavenging in mixed-phase clouds improves the comparison at sites where WBF dominates but degrades the comparison at sites where riming dominates. We attribute the discrepancy to several reasons. First, WBF is parameterized based on observations at a single site (Sect. 3.2); extrapolating it to global scale may introduce large uncertainties. Second, LWC, a key parameter that separates the two conditions (Sect. 3.2), is biased high and associated with large spatial discrepancies in GEOS-5 reanalysis (Li et al., 2012; Barahona et al., 2014). Third, this separation is based on a lab experiment (Fukuta nd Takahashi, 1999), while conditions in the real atmosphere are certainly more complex. This calls for more extensive measurements of $\mathrm{BC}$ scavenging efficiency in mixed-phase clouds to better understand the scavenging processes.

In addition to the uncertainties in differentiating rimingversus WBF-dominated in-cloud scavenging in mixed-phase clouds, uncertainties associated with other processes that determine the hygroscopicity, size and composition of $\mathrm{BC}$ particles also affect scavenging efficiency. Aged BC particles (e.g., coated by hydrophilic species) with higher hygroscopicity and larger size are more likely to be activated and serve as CCN (Wyslouzil et al., 1994; Weingartner et al., 1997; R. Zhang et al., 2008), and the scavenging efficiency is considerably higher than freshly emitted BC particles. Sellegri et al. (2003) reported scavenging efficiencies of $0.39 \pm 0.16$ for $\mathrm{BC}$ aerosols with diameters less than $0.3 \mu \mathrm{m}$ and hydrophilic material fractions less than $38 \%$. The scavenging efficiency increased to $0.97 \pm 0.02$ for particles with a diameter larger than $0.3 \mu \mathrm{m}$ and the fraction of hydrophilic material at $57 \%$ or higher. In this study, we assume $80 \%$ of freshly emitted BC particles are hydrophobic and externally mixed with co-emitted hydrophilic particles (Cooke et al., 1999). However, field observations show that the fraction systematically differs among urban plumes $(\sim 10 \%)$ and biomass burning plumes $(\sim 70 \%)$ (Schwarz et al., 2008). The simple assumption of $80 \%$ hydrophobic $\mathrm{BC}$ for all sources thus carries uncertainties for BC scavenging efficiency. Moreover, we assume hydrophobic BC particles are converted to hydrophilic with an $e$-folding time of 1.15 days (Park et al., 2005). However, the conversion is much faster (a few hours) in source regions where the concentration of hydrophilic materials is high, while the conversion is much slower in remote regions (a few days) (He et al., 2016). Therefore, the uniform conversion rate used in this study might underestimate the scavenging efficiency near source regions. In addition, faster conversion from hydrophobic to hydrophilic near sources might cause more hydrophilic BC particles to be scavenged near sources and thus alter the scavenging efficiency at remote regions. In addition, we assume all hydrophobic particles serve as ice nuclei. This simplification might also involve uncertainties in BC scavenging efficiency. First, current field observations and lab experiments show contradictory result for the ice nucleation ability of BC particles (Murray et al., 2012). Kamphus et al. (2010) found that soot particles were not enhanced in the ice phase compared to the background aerosol, while Cozic et al. (2008) found that the black carbon mass fraction was enhanced from $5 \%$ in the background to $27 \%$ in ice residues. Gorbunov et al. (2001) found that hydrophilic soot was 3-4 orders of magnitude more efficient at producing ice, while other studies (e.g., Andreae and Rosenfeld, 2008, and references therein) found that the ability of heterogeneous ice formation of pure hydrophobic soot particles is reduced by the presence of organic materials or sulfuric acid. Second, ice nucleation on soot particles is complex because soot particles from different combustion sources have different ice nucleating abilities (Murray et al., 2012, and references therein). 

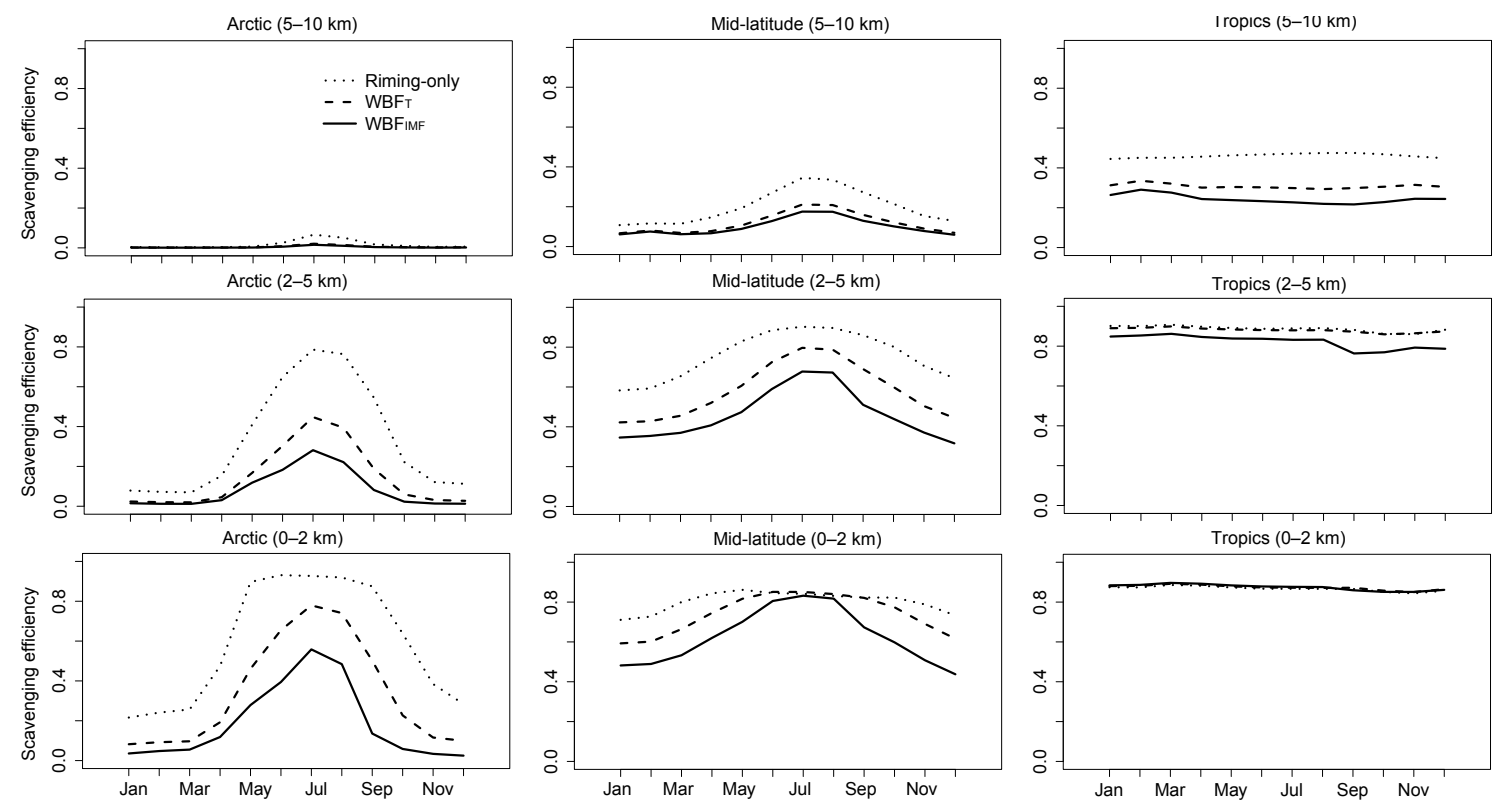

Figure 2. GEOS-Chem-simulated monthly mean BC scavenging efficiency in the Arctic $\left(60-90^{\circ} \mathrm{N}\right)$, mid-latitudes $\left(20-60^{\circ} \mathrm{N}\right)$ and the tropics $\left(0-20^{\circ} \mathrm{N}\right)$ in the boundary layer $(0-2 \mathrm{~km})$, the lower troposphere $(2-5 \mathrm{~km})$ and the middle to upper troposphere $(5-10 \mathrm{~km})$. Results are averages for 2007-2009.

\subsubsection{Seasonal variations of $\mathrm{BC}$ scavenging efficiency}

Figure 2 shows model-simulated monthly mean BC scavenging efficiencies in the Arctic, the northern mid-latitudes, and the tropics at $0-2,2-5$, and $5-10 \mathrm{~km}$ altitudes. The values are averaged for 2007-2009. BC scavenging efficiencies in the Arctic show strong seasonal cycle below $5 \mathrm{~km}$. If only the riming process in mixed-phase clouds is considered (experiment riming-only), BC scavenging efficiency is determined exclusively by its hygroscopicity (Wang et al., 2011). We find that more than $90 \%$ of BC particles in the Arctic are hydrophilic. In warm and mixed-phase clouds, hydrophilic BC particles serve as $\mathrm{CCN}$ and are incorporated in cloud water drops, while hydrophobic BC particles remain in the atmosphere (Wang et al., 2011). Figure 2 shows that in the middle and lower troposphere $(<5 \mathrm{~km})$, where most clouds are warm and mixed-phase in summer, BC scavenging efficiency is approximately the ratio of hydrophilic to total BC $(0.80-0.90)$. In ice clouds, hydrophobic BC particles serve as ice nuclei and are removed with the falling snowflakes, while scavenging of hydrophilic BC particles is suppressed completely (Wang et al., 2011). Consequently, when ice clouds dominate in most of the wintertime, BC scavenging efficiency is around the ratio of hydrophobic to total $\mathrm{BC}(\sim 0.10)$. WBF reduces $\mathrm{BC}$ scavenging efficiency by $22-69 \%$ in summer and by $63-85 \%$ in winter. In the upper troposphere $(>5 \mathrm{~km})$, where ice clouds dominate year-round, $\mathrm{BC}$ scavenging efficiency likewise is around the ratio of hydrophobic to total $\mathrm{BC}(\sim 0.1)$ and shows little to no seasonal variation.
In the northern mid-latitudes, the seasonal cycle of $\mathrm{BC}$ scavenging efficiency is weaker than that in the Arctic - the value in winter is much higher (0.4-0.6) in the mid-latitudes as a result of higher temperature and lower frequency of pure ice clouds (Zhang et al., 2010). WBF reduces BC scavenging efficiency by $17-44 \%$ in winter in the troposphere. The effect is relatively weaker than that in the Arctic (63-85\% reduction). In addition, the WBF effect increases with increasing altitude (from 0 at the surface to $39-50 \%$ in the upper troposphere), different from that in the Arctic.

In the tropics, the seasonal cycle of $\mathrm{BC}$ scavenging efficiency disappears in the lower troposphere in all three model experiments, for two reasons. First, temperature is high throughout the year and clouds are mostly warm clouds. Second, most of the tropical clouds are convective where strong updrafts suppress WBF by bringing abundant water vapor to the clouds (Liu et al., 2011). However, in the tropical upper troposphere, WBF reduces BC scavenging efficiency by $33-47 \%$ because the frequency of mixed-phase clouds is higher than that in the middle and lower troposphere.

\subsection{BC concentration in air}

GEOS-Chem captures the probability density function (PDF) of annual $\mathrm{BC}_{\mathrm{air}}$ at sites from IMPROVE and EMEP and in China and the Arctic (Sect. 2.2) but overestimates the frequency of low $\mathrm{BC}_{\text {air }}$ (experiment riming-only) (Fig. 3a). WBF releases BC in cloud water droplets back to the interstitial air and thus reduces BC scavenging efficiency and leaves more $\mathrm{BC}$ particles in the atmosphere (Sect. 4.1). As 

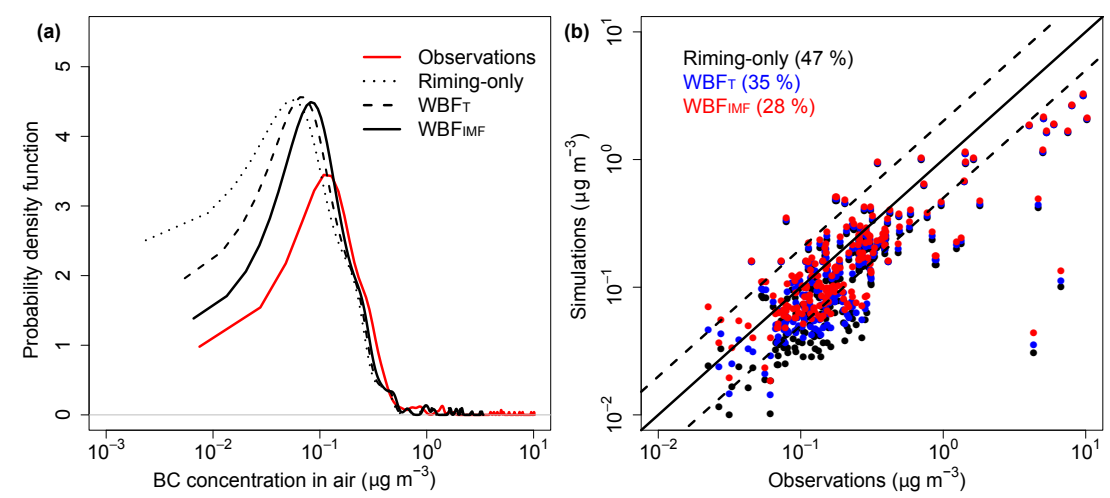

Figure 3. (a) Probability density function of observed (red line) and GEOS-Chem-simulated (dotted: riming; dashed: $\mathrm{WBF}_{\mathrm{T}}$; solid black: $\mathrm{WBF}_{\mathrm{IMF}}$ ) annual mean $\mathrm{BC}$ concentration in air $\left(\mu \mathrm{g} \mathrm{m}^{-3}\right)$ and (b) observed and simulated annual BC concentrations (black: riming; blue: $\mathrm{WBF}_{\mathrm{T}}$; red: $\mathrm{WBF}_{\mathrm{IMF}}$; the percentage of annual $\mathrm{BC}$ concentrations locate outside the $1: 2$ and $2: 1$ lines are in parentheses; solid line - $1: 1$ ratio line, dashed lines $-1: 2$ (or $2: 1$ ) ratio lines). Data are for 2007-2009. See text for details.

such, including the WBF effect increases $\mathrm{BC}_{\text {air }}$ and improves the agreement with observations compared with the control experiment, riming-only, particularly for the low values (Fig. 3a). WBF reduces the fraction of simulated $\mathrm{BC}_{\text {air }}$ that is underestimated by more than a factor of 2 (from 47 to 28 $35 \%$ ) (Fig. 3b). We use a ratio $r$ to quantify the effect of $\mathrm{WBF}$ on $\mathrm{BC}_{\mathrm{air}}$,

$r=\frac{[\mathrm{BC}]_{\mathrm{WBF}}-[\mathrm{BC}]_{\text {riming-only }}}{[B C]_{\text {riming-only }}}$,

where $r$ is a fraction that describes the simulated changes in $\mathrm{BC}_{\mathrm{air}}$ with $\mathrm{WBF}$ parameterizations relative to that with riming-only, and $[\mathrm{BC}]_{\mathrm{WBF}}$ and $[\mathrm{BC}]_{\text {riming-only }}$ are simulated $\mathrm{BC}_{\mathrm{air}}$ with and without $\mathrm{WBF}$ at the measurement stations (Sect. 2.2). The fraction $r$ is much larger in the Arctic (62$140 \%)$ than in the northern mid-latitudes (0-40\%) (Fig. 4a) for several reasons. First, the frequency of mixed-phase clouds is higher in the Arctic (41-90\% from spring to fall) than in the mid-latitudes $(\sim 20 \%)$ (Pinto 1998; Shupe et al., 2006; Zhang et al., 2010; Morrison et al., 2012). Second, lower temperature and higher IMF in the Arctic result in a stronger WBF effect. Third, WBF increases $\mathrm{BC}_{\text {air }}$ in the mid-latitudes and consequently the poleward transport of $\mathrm{BC}$. In addition, $\mathrm{WBF}$ increases $\mathrm{BC}_{\mathrm{air}}$ substantially in winter and spring and hence delays the transition of high $\mathrm{BC}_{\mathrm{air}}$ in winter to low $\mathrm{BC}_{\text {air }}$ in summer (Qi et al., 2017).

We find that $r$ increases with increasing altitude from surface $(6-12 \%)$ to $\sim 4 \mathrm{~km}(45-95 \%)$ (Fig. $4 \mathrm{~b})$. This is because as altitude increases, temperature decreases and IMF increases, resulting in a stronger WBF effect and thus larger reductions of $\mathrm{BC}$ scavenging efficiency in the mid-latitudes (Fig. 2). As a result, less BC is scavenged and more BC particles remain in the atmosphere. Figure 5 shows IMPROVE and GEOS-Chem-simulated monthly mean $\mathrm{BC}_{\text {air }}$. In summer, the model underestimates $\mathrm{BC}_{\text {air }}$ by $46-72 \%$. WBF increases $\mathrm{BC}_{\text {air }}$ and reduces the discrepancy to $35-58 \%$ (by $5-55 \%$ ) from the surface to $\sim 4 \mathrm{~km}$. The relative change in
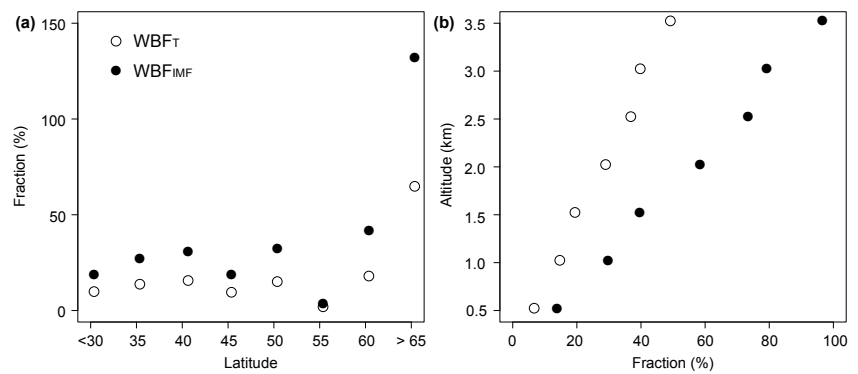

Figure 4. GESO-Chem-simulated fractional change to $\mathrm{BC}$ concentration, relative to riming-only, as a result of $\mathrm{WBF}$, $\left([\mathrm{BC}] \mathrm{WBF}-[\mathrm{BC}]_{\text {riming }}\right) /[\mathrm{BC}]_{\text {riming }}$ that varies with (a) altitude and (b) latitude, averaged for 2007-2009.

$\mathrm{BC}_{\mathrm{air}}$ increases from surface (6-22\%) to above $3 \mathrm{~km} \mathrm{(21-}$ $78 \%$ ). The largest discrepancy (54-58\%) is at $1.5-3 \mathrm{~km}$, where the influence of fire emissions is significantly underestimated (Mao et al., 2011, 2014). BC $_{\text {air }}$ is strongly underestimated in winter as well and the discrepancy increases monotonically with increasing altitude from $\sim 10 \%$ at the surface to $\sim 70 \%$ above $2.5 \mathrm{~km}$ in winter. WBF increases $\mathrm{BC}_{\text {air }}$ monotonically from $5 \%$ at the surface to $80-156 \%$ above $2.5 \mathrm{~km}$, reducing the discrepancy to within $30 \%$, particularly at higher altitudes. Above $2.5 \mathrm{~km}$, the discrepancy of $\mathrm{BC}_{\mathrm{air}}$ decreases from $67-70$ to $15-20 \%$. Cloud observations show not much riming or graupel snow particles and simulations over Montana and Nebraska in October-November suggest that rate of WBF is significantly larger than that of riming (Smith et al., 2009; Niu et al., 2008). WBF has little effect on $\mathrm{BC}_{\mathrm{air}}$ at sites in the lower troposphere in East Asia and Europe, where temperature is high and mixed-phase clouds rarely occur. 
Table 3. Observed and simulated precipitation (cm) and BC wet deposition fluxes $\left(\mathrm{mg} \mathrm{m}^{-2} \mathrm{yr}^{-1}\right)$.

\begin{tabular}{|c|c|c|c|c|c|c|c|}
\hline & & \multicolumn{2}{|c|}{ Precipitation $(\mathrm{cm})$} & \multicolumn{4}{|c|}{ BC wet deposition fluxes $\left(\mathrm{mg} \mathrm{m}^{-2} \mathrm{yr}^{-1}\right)$} \\
\hline & & \multirow[t]{2}{*}{ Observations } & \multirow[t]{2}{*}{ GEOS-5 } & \multirow[t]{2}{*}{ Observations } & \multicolumn{3}{|c|}{ Model } \\
\hline & & & & & Riming-only & $\mathrm{WBF}_{\mathrm{T}}$ & $\mathrm{WBF}_{\mathrm{IMF}}$ \\
\hline \multirow{4}{*}{ Continental } & $\begin{array}{l}\text { Schauinsland } \\
\left(47.9^{\circ} \mathrm{N}, 7.9^{\circ} \mathrm{E} ; 1.20 \mathrm{~km}\right)\end{array}$ & 157.4 & 81 & 38 & 21.2 & 20.4 & 18.3 \\
\hline & $\begin{array}{l}\text { Sonnblick } \\
\left(47^{\circ} \mathrm{N}, 13.4^{\circ} \mathrm{E} ; 3.11 \mathrm{~km}\right) \\
\text { K-puszta }\end{array}$ & 208.2 & 104.1 & 10 & 6.1 & 5.5 & 5.1 \\
\hline & $\left(47^{\circ} \mathrm{N}, 19.5^{\circ} \mathrm{E} ; 0.12 \mathrm{~km}\right)$ & 59.5 & 43.8 & 9.5 & 31.1 & 29.5 & 26.1 \\
\hline & $\begin{array}{l}\text { Changbai } \\
\left(42.5^{\circ} \mathrm{N}, 128.5^{\circ} \mathrm{E} ; 0.74 \mathrm{~km}\right)\end{array}$ & 10.4 & 17.7 & 29.3 & 53.8 & 29.7 & 18.1 \\
\hline \multirow{3}{*}{$\begin{array}{l}\text { Costal } \\
\text { and } \\
\text { oceanic }\end{array}$} & $\begin{array}{l}\text { Cape Hedo } \\
\left(26.9^{\circ} \mathrm{N}, 128.3^{\circ} \mathrm{E} ; 0.06 \mathrm{~km}\right) \\
\text { Azores }\end{array}$ & 198.5 & 138.2 & 52.5 & 59.1 & 61.2 & 64.1 \\
\hline & $\left(38.5^{\circ} \mathrm{N}, 27.3^{\circ} \mathrm{W} ; 0 \mathrm{~km}\right)$ & 113.2 & 57.6 & 5 & 4.6 & 5.7 & 7 \\
\hline & $\left(40.5^{\circ} \mathrm{N}, 8.6^{\circ} \mathrm{W} ; 0.05 \mathrm{~km}\right)$ & 72.9 & 51.3 & 7.5 & 9.8 & 10.5 & 11.2 \\
\hline Tropics & $\begin{array}{l}\text { Sakaerat } \\
\left(14.5^{\circ} \mathrm{N}, 101.9^{\circ} \mathrm{E} ; 0.04 \mathrm{~km}\right)\end{array}$ & 119.4 & 226.7 & 17.7 & 87.1 & 87 & 86.9 \\
\hline
\end{tabular}

\subsection{BC wet deposition fluxes}

Table 3 shows observed and GEOS-Chem-simulated annual BC wet deposition fluxes. GEOS-Chem captures the high deposition flux at Cape Hedo in the East China Sea $\left(52.5 \mathrm{mg} \mathrm{m}^{-2} \mathrm{yr}^{-1}\right.$ ) and the low deposition flux $\left(5.0 \mathrm{mg} \mathrm{m}^{-2} \mathrm{yr}^{-1}\right.$ ) at the Azores (within $40 \%$ ). Cape Hedo receives outflow of East Asia (Mori et al., 2014), while the Azores is mainly affected by clean marine air (Cerqueira et al., 2010). Wet deposition fluxes at Schauinsland and Sonnblick are underestimated by $\sim 50 \%$. One possible reason is the underestimated precipitation at the two sites. In contrast, at K-puszta and Sakaerat, BC wet deposition fluxes are overestimated by a factor of $2-5$. At K-puszta, $\mathrm{BC}$ in precipitation is overestimated, while $\mathrm{BC}_{\mathrm{air}}$ is underestimated (Sect. 4.4), indicating that wet scavenging is too strong during transit to the site. At Sakaerat, wet deposition is overestimated by a factor of 5 .

WBF has opposite effects on BC wet deposition fluxes near source regions over land and in remote regions over ocean. Over land, WBF reduces annual wet deposition fluxes by $\sim 15 \%$ at Schauinsland, Sonnblick and K-puszta. This is because of reduced $\mathrm{BC}$ scavenging efficiency $(5-45 \%)$. The largest effect of WBF is at Changbai, where WBF reduces BC wet deposition flux (November-April) by 45-66\% (from 53.8 to $18.1-29.7 \mathrm{mg} \mathrm{m}^{-2}$ ), reducing the discrepancy from +84 to $-40-0 \%$. In contrast, WBF increases wet deposition fluxes at oceanic sites Cape Hedo and the Azores and costal site Aveiro by $8-50 \%$, even with a lower local scavenging efficiency (7-20\% reduction at the oceanic sites). We find that the increase in wet deposition fluxes is mainly from enhanced outflow from polluted land regions as a result of WBF. In the tropics, WBF has a minimal effect on wet deposition flux $(<1 \%)$, for example at Sakaerat, because temperature at the site is above freezing throughout the year and mixed-phase clouds are very rare.

\subsection{BC concentration in snow}

Figure 6a presents the PDF of observed and GEOS-Chemsimulated $\mathrm{BC}_{\text {snow }}$ in the Northern Hemisphere (Sect. 2.3). Observed $\mathrm{BC}_{\text {snow }}$ shows a lognormal distribution and varies by 3 orders of magnitude from a minimum of $1.8 \mathrm{ng} \mathrm{g}^{-1}$ in the Arctic to a maximum of $4758 \mathrm{ng} \mathrm{g}^{-1}$ in northern China. The model (experiment riming-only) underestimates the frequency of $\mathrm{BC}_{\text {snow }}$ at $8-80 \mathrm{ng} \mathrm{g}^{-1}$, while it overestimates the frequency outside the range. More importantly, the observations have a single maximum but the model shows a bimodal structure. WBF significantly improves the agreement between observed and simulated distribution by increasing the frequency of $\mathrm{BC}_{\text {snow }}$ at $8-80 \mathrm{ng} \mathrm{g}^{-1}$, resulting in a single maximum. WBF decreases median $\mathrm{BC}_{\text {snow }}$ by $\sim 15 \%$ (from 25.7 to $22.4-22.7 \mathrm{ng} \mathrm{g}^{-1}$ ) and improves the comparison with observations (median: $19.1 \mathrm{ng} \mathrm{g}^{-1}$ ).

Figure $6 \mathrm{~b}$ shows observed and simulated medians of $\mathrm{BC}_{\text {snow }}$ in the nine subregions as defined in Sect. 2.3. Overall, GEOS-Chem captures the spatial distribution of $\mathrm{BC}_{\text {snow }}$ from lowest in the Arctic to highest in the Northeast Industrial region in northern China but overestimates $\mathrm{BC}_{\text {snow }}$ in the mid-latitudes (by up to a factor of 3 ) and underestimates 

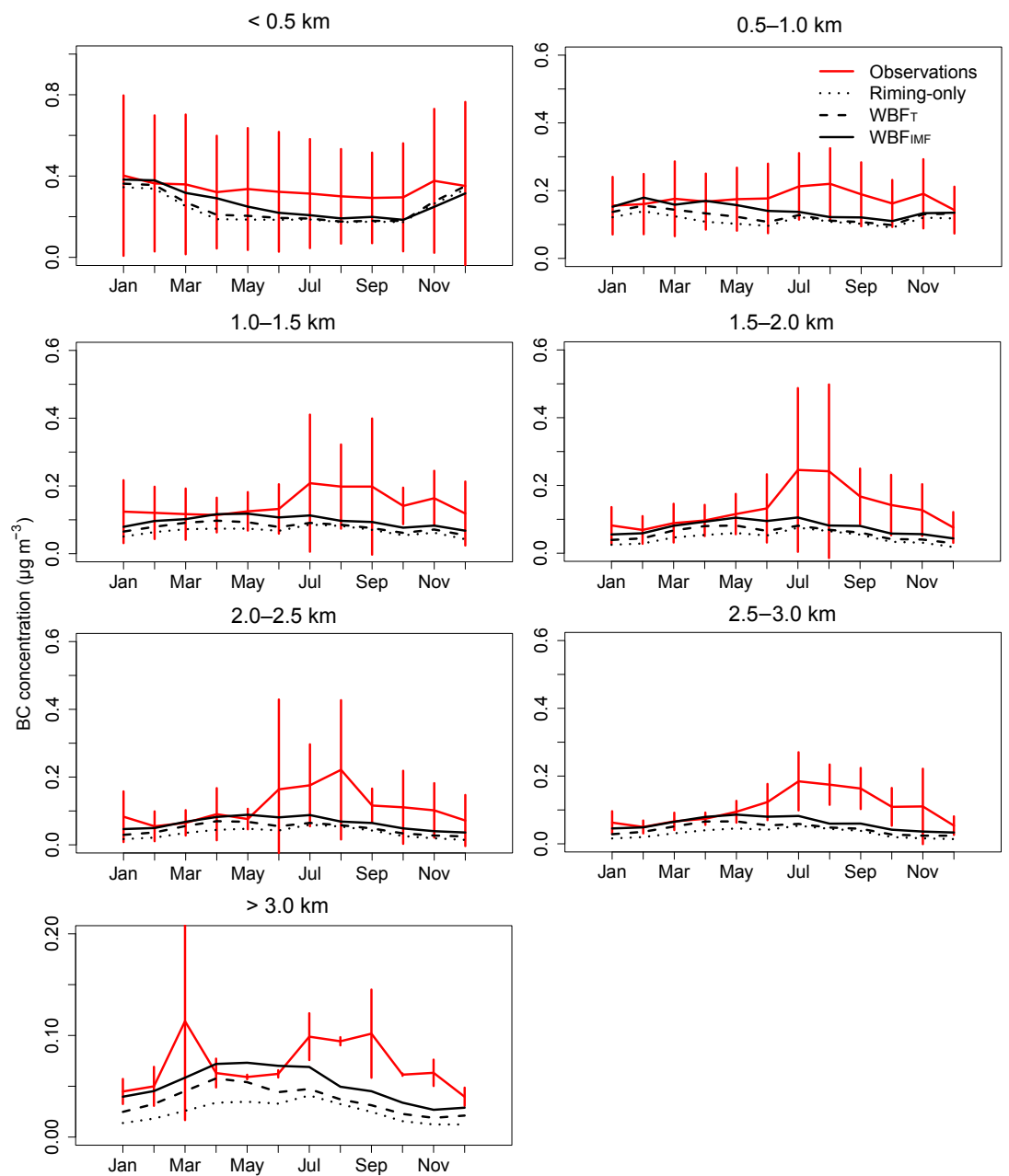

Figure 5. IMPROVE-observed (red solid line) and GEOS-Chem-simulated (dotted: riming-only; dashed: $\mathrm{WBF}_{\mathrm{T}}$; $\mathrm{solid}_{\mathrm{black}} \mathrm{WBF}_{\mathrm{IMF}}$ ) seasonal variation in monthly mean BC concentrations $\left(\mu \mathrm{g} \mathrm{m}^{-3}\right)$ for 2007-2009. Also shown are standard deviations of observations (error bars).
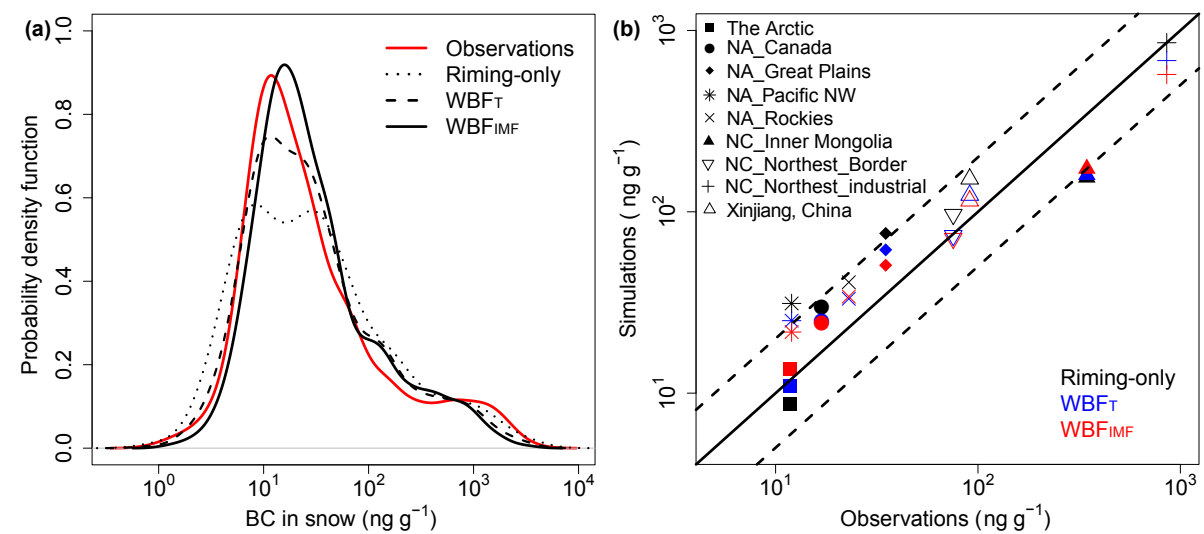

Figure 6. (a) Probability density function of observed (solid red line) and GEOS-Chem-simulated (dotted: riming-only; dashed: WBF solid black: $\mathrm{WBF}_{\mathrm{IMF}}$ ) BC in snow $\left(\mathrm{ngg}^{-1}\right)$ and $(\mathbf{b})$ medians of observed and simulated $\mathrm{BC}$ in snow (ng g ${ }^{-1}$ ) in the Arctic, North America (Canada, the Great Plains, the Pacific Northwest, and the Rockies, as defined by Doherty et al., 2014)), northern China (Inner Mongolia, Northeast Border and Northeast Industrial, as defined by Wang et al., 2013), and Xinjiang, China. The regions are symbol-coded and the simulations are color-coded (see text for details). Solid line $-1: 1$ ratio line; dashed lines $-1: 2$ (or $2: 1$ ) ratio lines. 
Table 4. GEOS-Chem simulations of global BC distribution.

\begin{tabular}{ll}
\hline Experiments & $\mathrm{BC}$ scavenging efficiency in large-scale mixed-phase clouds \\
\hline Riming-only (control) & Same as that in warm clouds, $r_{\text {scav. }}=\frac{\mathrm{BC}_{\text {hydrophylic }}}{\mathrm{BC}_{\text {total }}}$. \\
\hline $\mathrm{WBF}_{\mathrm{T}}$ & Smaller value of $r_{\text {scav. }}=0.003+\frac{0.66}{1+\frac{\exp (-T+9.32)}{6.77}}$ and $r_{\text {scav. }}=\frac{\mathrm{BC}_{\text {hydrophylic }}}{\mathrm{BC}_{\text {total }}}$ \\
\hline $\mathrm{WBF}_{\mathrm{IMF}}$ & Smaller value of $r_{\text {scav. }}=0.05+0.92 \cdot \exp (-8.95 \sqrt{\mathrm{IMF}})$ and $r_{\text {scav. }}=\frac{\mathrm{BC}_{\text {hydrophlic }}}{\mathrm{BC}_{\text {total }}}$ \\
\hline
\end{tabular}

Table 5. GEOS-Chem-simulated BC deposition fluxes $\left(\mathrm{mg} \mathrm{m}^{-2} \mathrm{month}^{-1}\right)$ in the Arctic (September-April), North America (NovemberFebruary), northern China (November-February) and western China (November-February), averaged for 2007-2009.

\begin{tabular}{llccc}
\hline & Region & Riming-only & $\mathrm{WBF}_{\mathrm{T}}$ & $\mathrm{WBF}_{\mathrm{IMF}}$ \\
\hline \multirow{5}{*}{ Total deposition } & Arctic & $0.14\left(0.12-0.18^{\mathrm{a}}\right)$ & $0.15\left(0.13-0.17^{\mathrm{a}},+7 \%\right)$ & $0.17\left(0.16-0.20^{\mathrm{a}},+21 \% \mathrm{~b}\right)$ \\
& N. America & $0.75(0.72-0.80)$ & $0.66(0.63-0.71,-12 \%)$ & $0.61(0.56-0.65,-19 \%)$ \\
& N. China & $3.83(3.80-3.88)$ & $3.02(2.83-3.25,-21 \%)$ & $2.92(2.61-3.24,-24 \%)$ \\
& Xinjiang, China & $1.22(1.07-1.43)$ & $0.95(0.87-1.00,-25 \%)$ & $0.84(0.83-0.85,-34 \%)$ \\
\hline \multirow{5}{*}{ Wet deposition } & Arctic & $0.10(0.08-0.13)$ & $0.08(0.06-0.10,-22 \%)$ & $0.07(0.06-0.09,-29 \%)$ \\
& N. America & $0.35(0.31-0.38)$ & $0.22(0.20-0.24,-37 \%)$ & $0.16(0.14-0.18,-54 \%)$ \\
& N. China & $1.52(0.83-1.96)$ & $0.68(0.41-0.89,-52 \%)$ & $0.52(0.34-0.65,-63 \%)$ \\
& Xinjiang, China & $0.67(0.47-0.88)$ & $0.36(0.27-0.46,-46 \%)$ & $0.22(0.17-0.25,-57 \%)$ \\
\hline \multirow{5}{*}{ Dry deposition } & Arctic & $0.04(0.03-0.04)$ & $0.07(0.06-0.08,+81 \%)$ & $0.10(0.09-0.11,+159 \%)$ \\
& N. America & $0.39(0.38-0.42)$ & $0.42(0.41-0.45,+7 \%)$ & $0.46(0.43-0.48,+16 \%)$ \\
& N. China & $2.31(2.10-2.55)$ & $2.37(2.15-2.61,+3 \%)$ & $2.42(2.20-2.65,+5 \%)$ \\
& Xinjiang, China & $0.52(0.47-0.57)$ & $0.56(0.51-0.61,+8 \%)$ & $0.59(0.55-0.64,+15 \%)$ \\
\hline
\end{tabular}

${ }^{a}$ The minimum and maximum deposition fluxes. ${ }^{b}$ The deposition flux difference (WBF - riming-only) relative to that from the riming-only simulation.

$\mathrm{BC}_{\text {snow }}$ in the Arctic (by $27 \%$ ). WBF reduces $\mathrm{BC}_{\text {snow }}$ by $16-$ $33 \%$ in the mid-latitudes (discrepancy reduced to within a factor of 2), while it increases $\mathrm{BC}_{\text {snow }}$ by $\sim 30 \%$ in the Arctic (discrepancy reduced to within $15 \%$ ). The improvements are due to the redistribution of $\mathrm{BC}$ deposition as a result of WBF. WBF reduces BC deposition fluxes (by 12-34\%) in North America, northern China, and Xinjiang, China, while it increases the flux in remote Arctic by (7-21\%) (Table 5). In the mid-latitudes, WBF reduces BC wet deposition fluxes (by 37-63\%), while it increases dry deposition fluxes (by $3-16 \%)$. This is because $\mathrm{BC}_{\text {air }}$ in the boundary layer is increased with the WBF effect (Sect. 4.2). The higher dry deposition flux partly offsets the lower wet deposition, resulting in a reduction of $12-34 \%$ in the total $\mathrm{BC}$ deposition flux. In the Arctic, BC wet deposition flux decreases by $21-$ $29 \%$, while dry deposition flux increases substantially by 81-159\%, much larger than that in the mid-latitude regions. As a result, the total deposition flux in the Arctic increases by $\sim 20 \%$.

Even with the WBF effect, $\mathrm{BC}_{\text {snow }}$ is still overestimated across much of the mid-latitudes. This indicates that $\mathrm{BC}$ scavenging over East Asia and North America is likely overestimated in the model during snow season. The exception is in Inner Mongolia and the Northern Industrial region in
China. In Inner Mongolia, snow samples were mixed with local soil and the measurements of $\mathrm{BC}_{\text {snow }}$ were associated with very large uncertainties (Wang et al., 2013). In addition, most of the snow samples in this region were taken from thick drifted snow layers; therefore, $\mathrm{BC}_{\text {snow }}$ does not correspond to $\mathrm{BC}$ deposition. In the Northern Industrial region (median: $856 \mathrm{ng} \mathrm{g}^{-1}$, significantly larger than the global median of $19 \mathrm{ng} \mathrm{g}^{-1}$ ), BC deposition is strongly affected by emissions from local sources and dry deposition flux. At Changbai, for instance, WBF significantly improves the simulation of wet deposition flux (discrepancy lowered from +80 to $-40-0 \%$, Table 3 ). However, dry deposition flux at the site is underestimated by a factor of 5 . Thus, the underestimate of $\mathrm{BC}_{\text {snow }}$ (by $34 \%$ ) in the region is likely because of the excessively low $\mathrm{BC}$ dry deposition.

\subsection{Washout ratio of $\mathrm{BC}$}

Hegg et al. (2011) reported that now particles mostly showed rimed structures at Zeppelin, resulting in high washout ratios ( 770, Table 2$)$. Model-simulated washout ratio with riming-only (experiment riming-only) is in agreement with observations to within a factor of 2 at Zeppelin. When snow particles are pristine crystal formed mainly from WBF, for example, at Abisko (Noone and Clark, 1988), the observed 

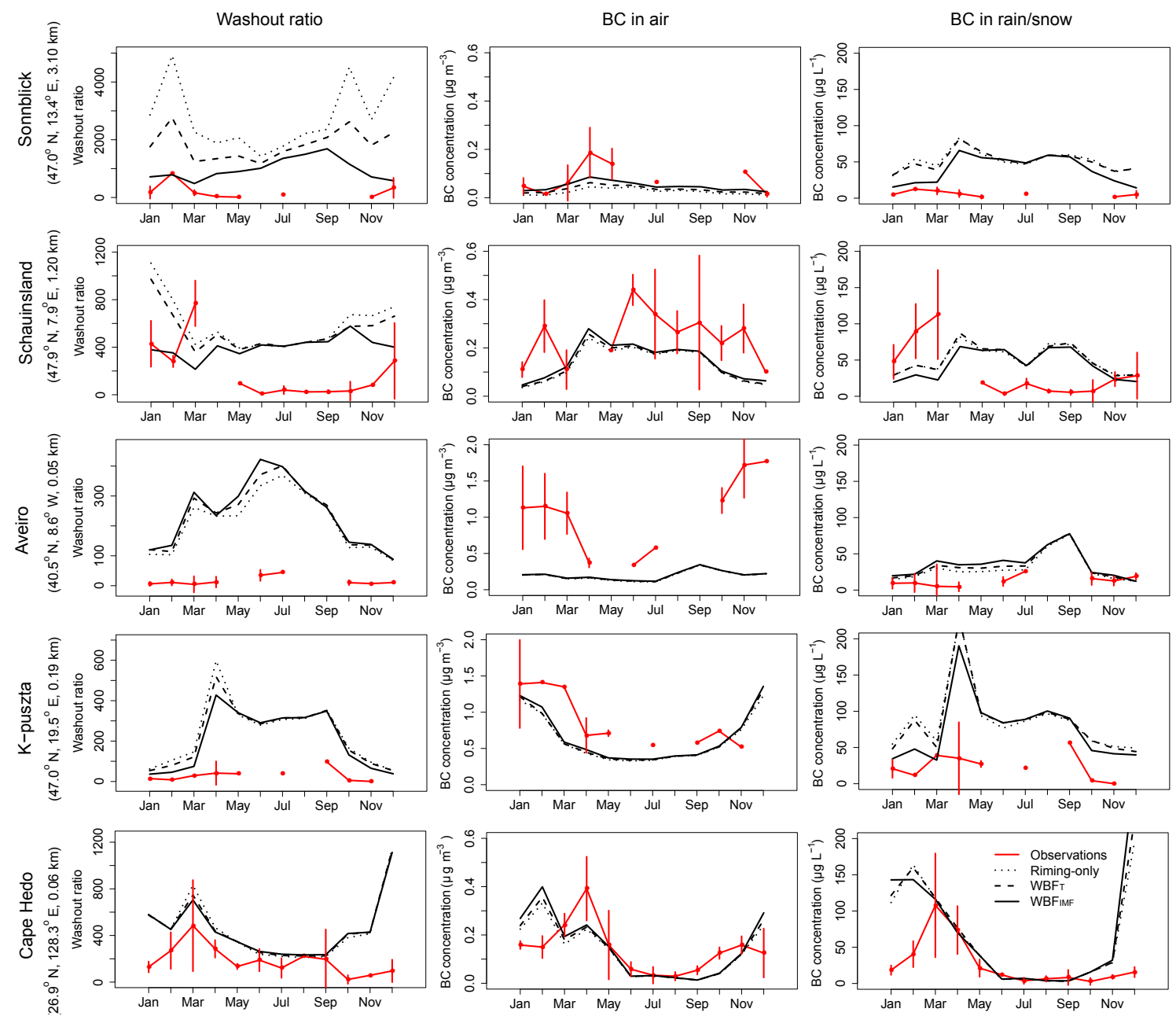

Figure 7. Observed and simulated BC washout ratio, BC concentration in surface air and in snow at Cape Hedo in the East China Sea, Aveiro and K-puszta (rural sites), and Schauinsland and Sonnblick (elevated sites).

washout ratios tend to be significantly lower (94 at Abisko and 145 at Changbai, Table 2). Modeled WBF reduces the washout ratio by a factor of 5 (from 482 to 96 ) and significantly lowers the discrepancy (from a factor of 4 to $2 \%$ ) at Abisko. WBF also drastically reduces the discrepancies at LAVO (from factors of 3-5 to 2).

Figure 7 shows observed and GEOS-Chem-simulated monthly mean $\mathrm{BC}$ washout ratios, $\mathrm{BC}_{\text {rain/snow }}$ and $\mathrm{BC}_{\text {air }}$ at four mountainous sites in Europe and at Cape Hedo. We use only simulations when daily mean precipitation is above the monthly median to compute monthly means, because samples of BC in rain/snow were collected during major rain/snow events (Cerqueira et al., 2010). At Sonnblick $(3.1 \mathrm{~km})$, a site that is constantly in the free troposphere, washout ratios are overestimated by orders of magnitude. This is because $\mathrm{BC}_{\text {rain/snow }}$ is overestimated, while $\mathrm{BC}_{\text {air }}$ is underestimated. WBF significantly reduces the discrepancy of washout ratios, particularly in winter (discrepancy lowered from factors of 4-16 to less that 4). The improve- ments are because $\mathrm{WBF}$ reduces $\mathrm{BC}_{\text {rain/snow }}$ (discrepancy reduced from a factor of 7 to a factor of 4) and increases $\mathrm{BC}_{\mathrm{air}}$ (discrepancy decreases from -77 to $-51 \%$ ). Remarkable improvement of washout ratio simulation is also seen at Schauinsland $(1.2 \mathrm{~km})$. WBF lowers the discrepancy of washout ratio in winter and spring from a factor of 2 to $\sim 20 \%$. However, this improvement is because of decreased $\mathrm{BC}$ in snow, which degrades the comparison with observations. WBF does not affect washout ratios at the three sealevel sites Aveiro $(0.47 \mathrm{~km})$, K-puszta $(0.19 \mathrm{~km})$, and Cape Hedo $(0.06 \mathrm{~km})$. That is because cloud processes have a rather limited effect on $\mathrm{BC}$ at the surface (Sect. 4.2). Even with the WBF effect, $\mathrm{BC}$ washout ratios are still largely overestimated, because $\mathrm{BC}_{\text {air }}$ is underestimated and $\mathrm{BC}_{\text {rain/snow }}$ is overestimated, particularly in summer. These overestimates suggest that wet deposition is likely too strong over Europe. 
Table 6. Global annual budget of BC. Ranges are given in parentheses.

\begin{tabular}{|c|c|c|c|c|c|c|c|c|}
\hline \multicolumn{2}{|c|}{ Model } & \multirow[t]{2}{*}{$\begin{array}{c}\text { Emissions } \\
\left(\mathrm{Tg} \mathrm{yr}^{-1}\right)\end{array}$} & \multicolumn{2}{|c|}{$\begin{array}{c}\text { Deposition } \\
\left(\mathrm{Tg}^{-1}{ }^{-1}\right)\end{array}$} & \multicolumn{2}{|c|}{ Mass loading } & \multirow[t]{2}{*}{$\begin{array}{r}\text { Lifetime } \\
\text { (day) }\end{array}$} & \multirow[t]{2}{*}{ References } \\
\hline & & & Dry & Wet & $\begin{array}{r}\text { Total } \\
\left(\mathrm{mg} \mathrm{m}^{-2}\right)\end{array}$ & $\begin{array}{r}>5 \mathrm{~km} \\
(\%)\end{array}$ & & \\
\hline \multirow{3}{*}{ GOES-Chem } & Riming-only & 8.5 & 1.5 & 6.9 & 0.22 & 21 & 5.7 & \multirow{7}{*}{ This study } \\
\hline & $\mathrm{WBF}_{\mathrm{T}}$ & 8.5 & 1.6 & 6.8 & 0.29 & 25 & 6.9 & \\
\hline & $\mathrm{WBF}_{\mathrm{IMF}}$ & 8.5 & 1.7 & 6.7 & 0.35 & 27 & 8.0 & \\
\hline \multirow{2}{*}{$\mathrm{WB}_{\mathrm{T}}$} & $248-273 \mathrm{~K}$ & 8.5 & 1.6 & 6.8 & 0.30 & 27 & 7.0 & \\
\hline & $258-268 \mathrm{~K}$ & 8.5 & 1.6 & 6.9 & 0.30 & 25 & 6.7 & \\
\hline \multirow{2}{*}{$\mathrm{WBF}_{\mathrm{IMF}}$} & $248-273 \mathrm{~K}$ & 8.5 & 1.7 & 6.7 & 0.36 & 29 & 8.0 & \\
\hline & $258-268 \mathrm{~K}$ & 8.5 & 1.6 & 6.8 & 0.32 & 26 & 7.0 & \\
\hline \multicolumn{2}{|l|}{ AeroCom I } & 6.3 & - & - & $0.25(0.16-0.38)$ & $21(18-41)$ & $7.3(4.9-11.4)$ & Schulz et al. (2006) \\
\hline \multicolumn{2}{|l|}{ AeroCom II } & $6.6-10.6$ & - & - & $0.14(0.07-0.31)$ & - & - & Myhre et al. (2013) \\
\hline \multicolumn{2}{|c|}{ AeroCom (median) } & 17 & - & - & $\sim 0.50$ & - & 6.1 & Bond et al. (2013) \\
\hline \multicolumn{2}{|l|}{ GEOS-Chem } & 6.5 & - & - & 0.08 & 9 & 4.2 & Q. Wang et al. (2014) \\
\hline \multicolumn{2}{|l|}{ GEOS-Chem } & 6.9 & - & - & 0.16 & 12 & 4.4 & X. Wang et al. (2014) \\
\hline \multicolumn{2}{|l|}{ GEOS-Chem } & 10.8 & - & - & 0.25 & 7 & 4.2 & He et al. (2016) \\
\hline
\end{tabular}

\section{Global BC budget}

Compared to AERONET observations of BC AAOD mainly over land, AeroCom models (I and II) underestimate BC loading by $60-160 \%$ (in South and Southeast Asia it is a factor of 3 and 4) (Bond et al., 2013). Bond et al. (2013) attributed the low bias to insufficient $\mathrm{BC}$ emissions. They then scaled $\mathrm{BC}$ emissions up according to the discrepancy of modeled versus observed BC AAOD and obtained a total global $\mathrm{BC}$ emission of $17 \mathrm{Tg} \mathrm{yr}^{-1}$, twice the median value used in the AeroCom models. They reported BC loading of $\sim 0.50 \mathrm{mg} \mathrm{m}^{-2}$ after scaling (Table 6). Our results suggest that the discrepancy can be partially explained by WBF not being accounted for in the AeroCom models. WBF increases global BC loading by $0.07-0.13 \mathrm{mg} \mathrm{m}^{-2}$ (by $32-60 \%$ ), depending on the WBF parameterizations used (based upon either temperature or IMF) (Table 6). Such increases are comparable to the median global $\mathrm{BC}$ loading from the AeroCom II models (Myhre et al., 2013). With WBF, our results show global BC loadings of $0.29-0.35 \mathrm{mg} \mathrm{m}^{-2}$, which is in remarkable agreement with the AERONET-based estimates (with scaled-up BC AAOD) as reported by Bond et al. (2013).

However, we find that, even with WBF, model results still have large biases over land, with $\mathrm{BC}_{\mathrm{air}}$ biased low (Figs. 3 and 5), $\mathrm{BC}_{\text {snow }}$ biased high (Fig. 6), and washout ratios too large (Fig. 7). These remaining discrepancies likely point toward excessive wet scavenging over land in the model. In North America, for instance, model-simulated $\mathrm{BC}_{\text {snow }}$ is too high by $\sim 50 \%$ (Fig. 6) and $\mathrm{BC}_{\text {air }}$ in winter (IMPROVE, Fig. 5) is low by up to $\sim 30 \%$. Additionally, model- simulated washout ratio at LAVO, California, is twice the observed value. In Europe, model-simulated washout ratios, particularly in summer, are excessively high, a result of overly high $\mathrm{BC}_{\text {rain/snow }}$ and too low $\mathrm{BC}_{\text {air }}$ predicted by the model (Fig. 7).

In contrast, compared to HIPPO over the remote Pacific, AeroCom models overestimate $\mathrm{BC}_{\text {air }}$ by a factor of 2 to 5 (Schwarz et al., 2010). To narrow the gap between model results and HIPPO observations, previous studies resorted to either enhancing wet scavenging or accelerating $\mathrm{BC}$ aging near source regions. For example, Q. Wang et al. (2014) included scavenging of hydrophobic $\mathrm{BC}$ in convective updrafts and hydrophilic BC in cold clouds $(<258 \mathrm{~K})$ by homogeneous freezing of solution droplets, neither of which was accounted for previously (Q. Wang et al., 2014). X. Wang et al. (2014) and He et al. (2016) used faster BC aging schemes, which led to stronger wet scavenging close to source regions and consequently weaker outflow from these regions. The $\mathrm{BC}$ loadings were estimated to be $0.08 \mathrm{mg} \mathrm{m}^{-2}$ (Q. Wang et al., 2014), $0.16 \mathrm{mg} \mathrm{m}^{-2}$ (X. Wang et al., 2014) and $0.25 \mathrm{mg} \mathrm{m}^{-2}$ (He et al., 2016), much lower than those constrained from AERONET measurements $\left(\sim 0.50 \mathrm{mg} \mathrm{m}^{-2}\right.$; Bond et al., 2013).

However, even with a faster aging scheme and stronger wet deposition, simulated $\mathrm{BC}_{\text {air }}$ is still biased high by a factor of 2-3 relative to HIPPO observations over the remote Pacific. The remaining high bias is likely a result of either excessive Asian outflow of BC or insufficient scavenging of BC over the Pacific. At Cape Hedo in the East China Sea (directly downwind of major sources in eastern China), modelsimulated $\mathrm{BC}_{\text {rain }}$ is an order of magnitude too high, while 
$\mathrm{BC}_{\mathrm{air}}$ is $50 \%$ too large in October-January (Fig. 7). This overestimate of wintertime outflow of $\mathrm{BC}$ from the region is likely the reason for the overestimate of $\mathrm{BC}_{\mathrm{air}}$ over the $\mathrm{Pa}$ cific in winter. Outside of winter, simulated $\mathrm{BC}_{\mathrm{air}}$ and $\mathrm{BC}_{\mathrm{rain}}$ at the site both agree with observations (within $50 \%$, Fig. 7). This suggests that the overestimate of $\mathrm{BC}_{\text {air }}$ over the Pacific is likely the result of insufficient removal over the Pacific.

WBF results in more BC particles in the upper troposphere (Table 6). As a result, there is a significantly higher fraction of BC loading above $5 \mathrm{~km}$ altitude (from 21 to 25 $29 \%$ ). This larger fraction, as expected, enhances the top-ofthe-atmosphere absorption forcing efficiencies (forcing per aerosol absorption optical depth; Bond et al., 2013) because of larger solar fluxes at higher altitudes (Bond et al., 2013; Samset and Myhre, 2011). The aforementioned fraction (25$29 \%$ ) falls in the range of AeroCom I model results (Schulz et al., 2006) but is 3 times higher than those constrained by HIPPO observations (9-12\%) (Q. Wang et al., 2014; $\mathrm{X}$. Wang et al., 2014). Moreover, WBF increases BC lifetime from 5.7 to $6.9-8.0$ days, an increase of up to $40 \%$. These longer lifetimes fall within the range of the AeroCom I model results (4.9-11.4 days) but at the higher end (Schulz et al., 2006). However, these lifetimes are nearly twice as long as those constrained by HIPPO observations (Q. Wang et al., 2014; X. Wang et al., 2014).

The temperature threshold for mixed-phase clouds and ice clouds is very uncertain and controlled by processes such as the shattering of isolated drops during freezing and the production of ice splinters during riming (Gayet et al., 2009; Browse et al., 2012), which are not explicitly accounted for in GEOS-Chem. To examine the sensitivity of BC distribution to various threshold temperatures, we conduct additional simulations. In the standard simulation, clouds are assumed to be mixed-phase at $258-273 \mathrm{~K}$. In the sensitivity studies, we vary the threshold between 268 and $248 \mathrm{~K}$. The results are summarized in Table 6 . The resulting BC deposition, loading, and lifetime are within $15 \%$ of the standard simulation. This suggests that our results are rather insensitive to the threshold temperature.

\section{Conclusions and implications}

We used GEOS-Chem (version 9-01-03) driven by GEOS5 assimilated meteorological fields to investigate the effects of WBF on global BC distribution. Specifically, we evaluated model simulations against observations of $\mathrm{BC}$ scavenging efficiencies, $\mathrm{BC}_{\text {air }}, \mathrm{BC}$ deposition fluxes, $\mathrm{BC}_{\mathrm{rain} / \text { snow }}$, and $\mathrm{BC}$ washout ratios. We distinguished riming- from WBFdominated conditions in mixed-phase clouds based upon temperature and liquid water content following a lab experiment from Fukuta and Takahashi (1999). We then related the WBF effect based on either temperature or ice mass fraction following Cozic et al. (2007).
The model reproduced the observed low scavenging efficiencies of $\mathrm{BC}$ near source regions and high scavenging efficiencies in remote regions. WBF lowered $\mathrm{BC}$ scavenging efficiencies at all altitudes and significantly improved the simulations at higher altitudes (such as Jungfraujoch, $3.85 \mathrm{~km}$, and Puy de Dôme, $1.47 \mathrm{~km}$ ). On average, in northern midlatitudes, WBF reduced BC scavenging efficiency by $17-$ $44 \%$ in winter, depending on the WBF parameterizations used. In summer, the effect increased with increasing altitude (from 0 at the surface to $39-50 \%$ in the upper troposphere). Across the Arctic, WBF reduced BC scavenging efficiency by $22-69 \%$ in summer and $63-85 \%$ in winter in the lower and middle troposphere. As a result, WBF increased $\mathrm{BC}_{\text {air }}$ $(<4 \mathrm{~km})$ globally and halved the discrepancy (from -65 to $-30 \%)$. The improvements were larger for sites at higher altitudes and latitudes.

The model captured the observed large BC wet deposition flux $\left(52.5 \mathrm{mg} \mathrm{m}^{-2} \mathrm{yr}^{-1}\right)$ at Cape Hedo in the East China Sea and comparatively low value $\left(5.0 \mathrm{mg} \mathrm{m}^{-2} \mathrm{yr}^{-1}\right)$ at the Azores in the central Atlantic. WBF resulted in lower wet deposition fluxes near source regions over land (by $\sim 15 \%$ ) but higher wet deposition fluxes over remote oceans (by $\sim 30 \%$ ). In addition, WBF lowered BC deposition fluxes (by $12-34 \%$ ) at mid-latitudes, while it enhanced the fluxes (by $2-19 \%$ ) in the Arctic. The former was because of the strong reduction of $\mathrm{BC}$ wet deposition fluxes (by 37-63\%) and the latter was from the strong enhancement of dry deposition fluxes (by $81-159 \%$ ). Thus, $\mathrm{BC}_{\text {snow }}$ decreased (by $15 \%$ ) in mid-latitudes and increased (by $26 \%$ ) in the Arctic as a result of the WBF effect. Overall, WBF lowered the discrepancy of $\mathrm{BC}_{\text {snow }}$ from 35 to $17 \%$, indicating that $\mathrm{WBF}$ explained a large fraction of the high bias of the model results. In addition, WBF significantly lowered the discrepancies of washout ratios of $\mathrm{BC}$ in winter from a factor of 16 to 4. In summer, washout ratios were overestimated by orders of magnitudes. WBF corrected a fraction of the biases. Reasons for the large overestimate warrant further investigation.

WBF increased global BC loading by $60 \%$ (from 0.22 to $0.35 \mathrm{mg} \mathrm{m}^{-2} \mathrm{yr}^{-1}$ ) and partially explained the low biases of AAOD from the AeroCom models (Bond et al., 2013). In addition, WBF increased the fraction of BC loading above $5 \mathrm{~km}$ (from 21 to $25-29 \%$ ) and hence a larger absorption forcing efficiency of BC. BC lifetime was longer by $40 \%$ (from 5.7 to 8.0 days) from the WBF effect.

On average, model simulations of $\mathrm{BC}$ scavenging efficiencies, $\mathrm{BC}_{\mathrm{air}}$, deposition fluxes, $\mathrm{BC}_{\text {rain/snow }}$, and washout ratios improved significantly. However, the comparisons degraded at riming-dominated sites, for example, Zeppelin. These results suggest that more observations are needed to better differentiate WBF- versus riming-dominated scavenging of BC. In addition, measurements of $\mathrm{BC}$ scavenging efficiencies in mixed-phase clouds at different latitudes and altitudes should be conducted, especially over the oceans, where there are scarce measurements of BC scavenging efficiency. Finally, WBF and riming are subgrid-scale processes that strongly 
depend on local variables, such as local updraft velocity, local vapor pressure, distribution of cold water drops and ice crystals in mixed-phase clouds and so on. Coupling a cloudresolving model with detailed cloud microphysics is necessary to better estimate the rate of $\mathrm{WBF}$ and riming and to better identify their roles in global $\mathrm{BC}$ distribution.

Data availability. The data used in this study are available from the corresponding author upon request (qiling@atmos.ucla.edu).

Competing interests. The authors declare that they have no conflict of interest.

Acknowledgements. This study was funded by NASA grant NNX14AF11G from the Atmospheric Chemistry Modeling and Analysis Program (ACMAP). The GEOS-5 data used in this study/project were provided by the Global Modeling and Assimilation Office (GMAO) at NASA Goddard Space Flight Center. The authors thank Joshua P. Schwarz, Betty Croft, Hongyu Liu for helpful discussions. We thank the two reviewers for their constructive comments.

Edited by: Barbara Ervens

Reviewed by: two anonymous referees

\section{References}

Andreae, M. O. and Rosenfeld, D.: Aerosol-cloud-precipitation interactions. Part 1. The nature and sources of cloud-active aerosols, Earth-Sci. Rev., 89, 13-41, 2008.

Barahona, D., Molod, A., Bacmeister, J., Nenes, A., Gettelman, A., Morrison, H., Phillips, V., and Eichmann, A.: Development of two-moment cloud microphysics for liquid and ice within the NASA Goddard Earth Observing System Model (GEOS-5), Geosci. Model Dev., 7, 1733-1766, https://doi.org/10.5194/gmd7-1733-2014, 2014.

Bergeron, T.: On the physics of clouds and precipitation. Proces Verbaux de l'Association de Météorologie, International Union of Geodesy and Geophysics, Imprimerie Paul Dupont, Paris, France, 156-178, 1935.

Bond, T. C., Bhardwaj, E., Dong, R., Jogani, R., Jung, S., Roden, C., Streets, D. G., and Trautmann, N. M.: Historical emissions of black and organic carbon aerosol from energy-related combustion, 1850-2000, Global Biogeochem. Cy., 21, GB2018, https://doi.org/10.1029/2006gb002840, 2007.

Bond, T. C., Doherty, S. J., Fahey, D. W., Forster, P. M., Berntsen, T., DeAngelo, B. J., Flanner, M. G., Ghan, S., Kärcher, B., Koch, D., Kinne, S., Kondo, Y., Quinn, P. K., Sarofim, M. C., Schultz, M. G., Schulz, M., Venkataraman, C., Zhang, H., Zhang, S., Bellouin, N., Guttikunda, S. K., Hopke, P. K., Jacobson, M. Z., Kaiser, J. W., Klimont, Z., Lohmann, U., Schwarz, J. P., Shindell, D., Storelvmo, T., Warren, S. G., and Zender, C. S.: Bounding the role of black carbon in the climate system: A sci- entific assessment, J. Geophys. Res.-Atmos., 118, 5380-5552, https://doi.org/10.1002/jgrd.50171, 2013.

Bourgeois, Q. and Bey, I.: Pollution transport efficiency toward the Arctic: Sensitivity to aerosol scavenging and source regions, J. Geophys. Res., 116, D08213, https://doi.org/10.1029/2010jd015096, 2011.

Browse, J., Carslaw, K. S., Arnold, S. R., Pringle, K., and Boucher, O.: The scavenging processes controlling the seasonal cycle in Arctic sulphate and black carbon aerosol, Atmos. Chem. Phys., 12, 6775-6798, https://doi.org/10.5194/acp12-6775-2012, 2012.

Castro, L. M., Pio, C. A., Harrison, R. M., and Smith, D. J. T.: Carbonaceous aerosol in urban and rural European atmospheres: Estimation of secondary organic carbon concentrations, Atmos. Environ., 33, 2771-2781, 1999.

Cerqueira, M., Pio, C., Legrand, M., Puxbaum, H., KasperGiebl, A., Afonso, J., Preunkert, S., Gelencsér, A., and Fialho, P.: Particulate carbon in precipitation at European background sites, J. Aerosol Sci., 41, 51-61, https://doi.org/10.1016/j.jaerosci.2009.08.002, 2010.

Chow, J. C., Watson, J. G., Pritchett, L. C., Pierson, W. R., Frazier, C. A., and Purcell, R. G.: The Dri Thermal Optical Reflectance Carbon Analysis System - Description, Evaluation and Applications in United-States Air-Quality Studies, Atmos. Environ. A-Gen., 27, 1185-1201, https://doi.org/10.1016/09601686(93)90245-T, 1993.

Chow, J. C., Watson, J. G., Chen, L. W. A., Arnott, W. P., Moosmuller, H., and Fung, K.: Equivalence of elemental carbon by thermal/optical reflectance and transmittance with different temperature protocols, Environ. Sci. Technol., 38, 4414-4422, https://doi.org/10.1021/Es034936u, 2004.

Cooke, W. F., Liousse, C., Cachier, H., and Feichter, J.: Construction of a $1^{\circ} \times 1^{\circ}$ fossil fuel emission data set for carbonaceous aerosol and implementation and radiative impact in the ECHAM4 model, J. Geophys. Res., 104, 22137-22162, https://doi.org/10.1029/1999jd900187, 1999.

Cozic, J., Verheggen, B., Mertes, S., Connolly, P., Bower, K., Petzold, A., Baltensperger, U., and Weingartner, E.: Scavenging of black carbon in mixed phase clouds at the high alpine site Jungfraujoch, Atmos. Chem. Phys., 7, 1797-1807, https://doi.org/10.5194/acp-7-1797-2007, 2007.

Cozic, J., Mertes, S., Verheggen, B., Cziczo, D. J., Gallavardin, S., Walter, S., Baltensperger, U., and Weingartner, E.: Black carbon enrichment in atmospheric ice particle residuals observed in lower tropospheric mixed phase clouds, J. Geophys. Res., 113, D15209, https://doi.org/10.1029/2007JD009266, 2008.

Doherty, S. J., Warren, S. G., Grenfell, T. C., Clarke, A. D., and Brandt, R. E.: Light-absorbing impurities in Arctic snow, Atmos. Chem. Phys., 10, 11647-11680, https://doi.org/10.5194/acp-1011647-2010, 2010.

Doherty, S. J., Dang, C., Hegg, D. A., Zhang, R. D., and Warren, S. G.: Black carbon and other light-absorbing particles in snow of central North America, J. Geophys. Res.-Atmos., 119, 1280712831, https://doi.org/10.1002/2014jd022350, 2014.

EUROPA: Directive 2008/50/EC of the European Parliament and of the Council, Official Journal of the European Union, 152 pp., 2008

EMEP/MSC-W, EMEP/CCC, EMEP/CEIP, IDAEA-CSIC, CCE/RIVM, and FMI: Transboundary particulate matter, 
photo-oxidants, acidifying and eutrophying components, Meteorologisk Institutt (Norwegian Meteorological Institute), EMEP Report 1/2014, 216 pp., 2014.

Findeisen, W.: Kolloid-meteorologische Vorgänge bei Neiderschlags-bildung, Meteorol. Z., 55, 121-133, 1938.

Flanner, M. G., Zender, C. S., Randerson, J. T., and Rasch, P. J.: Present-day climate forcing and response from black carbon in snow, J. Geophys. Res., 112, D11202, https://doi.org/10.1029/2006JD008003, 2007.

Fukuta, N. and Takahashi, T.: The Growth of Atmospheric Ice Crystals: A Summary of Findings in Vertical Supercooled Cloud Tunnel Studies, J. Atmos. Sci., 56, 1963-1979, https://doi.org/10.1175/15200469(1999)056<1963:TGOAIC>2.0.CO;2, 1999.

Gayet, J., Treffeisen, R., Helbig, A., Bareiss, J., Matsuki, A., Herber, A., and Schwarzenboeck, A.: On the onset of the ice phase in boundary layer Arctic clouds, J. Geophys. Res., 114, D19201, https://doi.org/10.1029/2008JD011348, 2009.

Ghan, S. J., Abdul-Razzak, H., Nenes, A., Ming, Y., Liu, X., Ovchinnikov, M., Shipway, B., Meskhidze, N., Xu, J., and Shi, X.: Droplet nucleation: Physically-based parameterizations and comparative evaluation, Journal of Advances in Modeling Earth Systems, 3, M10001, https://doi.org/10.1029/2011ms000074, 2011.

Gieray, R., Wieser, P., Engelhardt, T., Swietlicki, E., Hansson, H. C., Mentes, B., Orsini, D., Martinsson, B., Svenningsson, B., Noone, K. J., and Heintzenberg, J.: Phase partitioning of aerosol constituents in cloud based on single-particle and bulk analysis, Atmos. Environ., 31, 2491-2502, https://doi.org/10.1016/S13522310(96)00298-1, 1997.

Gilardoni, S., Massoli, P., Giulianelli, L., Rinaldi, M., Paglione, M., Pollini, F., Lanconelli, C., Poluzzi, V., Carbone, S., Hillamo, R., Russell, L. M., Facchini, M. C., and Fuzzi, S.: Fog scavenging of organic and inorganic aerosol in the Po Valley, Atmos. Chem. Phys., 14, 6967-6981, https://doi.org/10.5194/acp14-6967-2014, 2014.

Giorgi, F. and Chameides, W. L.: Rainout lifetimes of highly soluble aerosols and gases as inferred from simulations with a general circulation model, J. Geophys. Res., 91, 14367-14376, https://doi.org/10.1029/JD091iD13p14367, 1986.

Gorbunov, B., Baklanov, A., Kakutkina, N., Windsor, H., and Toumi, R.: Ice nucleation on soot particles, J. Aerosol Sci., 32, 199-215, 2001.

Hadley, O. L., Corrigan, C. E., and Kirchstetter, T. W.: Modified Thermal-Optical Analysis Using Spectral Absorption Selectivity To Distinguish Black Carbon from Pyrolized Organic Carbon, Environ. Sci. Technol., 42, 8459-8464, https://doi.org/10.1021/Es800448n, 2008.

Hadley, O. L., Corrigan, C. E., Kirchstetter, T. W., Cliff, S. S., and Ramanathan, V.: Measured black carbon deposition on the Sierra Nevada snow pack and implication for snow pack retreat, Atmos. Chem. Phys., 10, 7505-7513, https://doi.org/10.5194/acp10-7505-2010, 2010.

Hallberg, A., Ogren, J. A., Noone, K. J., Heintzenberg, J., Berner, A., Solly, I., Kruisz, C., Reischl, G., Fuzzi, S., Facchini, M. C., Hansson, H. C., Wiedensohler, A., and Svenningsson, I. B.: Phase Partitioning for Different Aerosol Species in Fog, Tellus B, 44, 545-555, https://doi.org/10.1034/j.16000889.1992.t01-2-00008.x, 1992.
Hallberg, A., Noone, K. J., Ogren, J. A., Svenningsson, I. B., Flossmann, A., Wiedensohler, A., Hansson, H. C., Heintzenberg, J., Anderson, T. L., Arends, B. G., and Maser, R.: Phase Partitioning of Aerosol Particles in Clouds at Kleiner Feldberg, in: The Kleiner Feldberg Cloud Experiment 1990: EUROTRAC Subproject Ground-Based Cloud Experiment (GCE), edited by: Fuzzi, S., Springer Netherlands, Dordrecht, 107-127, 1994.

He, C., Li, Q. B., Liou, K. N., Zhang, J., Qi, L., Mao, Y., Gao, M., Lu, Z., Streets, D. G., Zhang, Q., Sarin, M. M., and Ram, K.: A global 3-D CTM evaluation of black carbon in the Tibetan Plateau, Atmos. Chem. Phys., 14, 7091-7112, https://doi.org/10.5194/acp-14-7091-2014, 2014a.

He, C., Li, Q. B., Liou, K. N., Takano, Y., Gu, Y., Qi, L., Mao, Y. H., and Leung, L. R.: Black carbon radiative forcing over the Tibetan Plateau, Geophys. Res. Lett., 41, 7806-7813, https://doi.org/10.1002/2014gl062191, 2014b.

He, C., Li, Q., Liou, K.-N., Qi, L., Tao, S., and Schwarz, J. P.: Microphysics-based black carbon aging in a global CTM: constraints from HIPPO observations and implications for global black carbon budget, Atmos. Chem. Phys., 16, 3077-3098, https://doi.org/10.5194/acp-16-3077-2016, 2016.

Hegg, D. A., Clarke, A. D., Doherty, S. J., and Ström, J.: Measurements of black carbon aerosol washout ratio on Svalbard, Tellus B, 63, 891-900, https://doi.org/10.1111/j.16000889.2011.00577.x, 2011.

Heintzenberg, J. and Leck, C.: Seasonal-Variation of the Atmospheric Aerosol near the Top of the Marine Boundary-Layer over Spitsbergen Related to the Arctic Sulfur Cycle, Tellus B, 46, 5267, https://doi.org/10.1034/j.1600-0889.1994.00005.x, 1994.

Henning, S., Bojinski, S., Diehl, K., Ghan, S., Nyeki, S., Weingartner, E., Wurzler, S., and Baltensperger, U.: Aerosol partitioning in natural mixed-phase clouds, Geophys. Res. Lett., 31, L06101, https://doi.org/10.1029/2003GL019025, 2004.

Hitzenberger, R., Berner, A., Kromp, R., Kasper-Giebl, A., Limbeck, A., Tscherwenka, W., and Puxbaum, H.: Black carbon and other species at a high-elevation European site (Mount Sonnblick, $3106 \mathrm{~m}$, Austria): Concentrations and scavenging efficiencies, J. Geophys. Res., 105, 24637, https://doi.org/10.1029/2000jd900349, 2000.

Hitzenberger, R., Berner, A., Giebl, H., Drobesch, K., Kasper-Giebl, A., Loeflund, M., Urban, H., and Puxbaum, H.: Black carbon (BC) in alpine aerosols and cloud water - concentrations and scavenging efficiencies, Atmos. Environ., 35, 5135-5141, 2001.

Huang, J. P., Fu, Q. A., Zhang, W., Wang, X., Zhang, R. D., Ye, H., and Warren, S. G.: Dust and Black Carbon in Seasonal Snow across Northern China, B. Am. Meteorol. Soc., 92, 175-181, https://doi.org/10.1175/2010bams3064.1, 2011.

IPCC: Climate Change 2014: Synthesis Report. Contribution of Working Groups I, II and III to the Fifth Assessment Report of the Intergovernmental Panel on Climate Change, edited by: Core Writing Team, Pachauri, R. K., and Meyer, L. A., IPCC, Geneva, Switzerland, 151 pp., 2014.

Kamphus, M., Ettner-Mahl, M., Klimach, T., Drewnick, F., Keller, L., Cziczo, D. J., Mertes, S., Borrmann, S., and Curtius, J.: Chemical composition of ambient aerosol, ice residues and cloud droplet residues in mixed-phase clouds: single particle analysis during the Cloud and Aerosol Characterization Experiment (CLACE 6), Atmos. Chem. Phys., 10, 8077-8095, https://doi.org/10.5194/acp-10-8077-2010, 2010. 
Koch, D., Menon, S., Del Genio, A., Ruedy, R., Alienov, I., and Schmidt, G. A.: Distinguishing Aerosol Impacts on Climate over the Past Century, J. Climate, 22, 2659-2677, https://doi.org/10.1175/2008jcli2573.1, 2009.

Kondo, Y., Sahu, L., Moteki, N., Khan, F., Takegawa, N., Liu, X., Koike, M., and Miyakawa, T.: Consistency and traceability of black carbon measurements made by laser-induced incandescence, thermal-optical transmittance, and filter-based photo-absorption techniques, Aerosol Sci. Tech., 45, 295-312, https://doi.org/10.1080/02786826.2010.533215, 2011.

Li, J. L. F., Waliser, D. E., Chen, W. T., Guan, B., Kubar, T., Stephens, G., Ma, H. Y., Deng, M., Donner, L., Seman, C., and Horowitz, L.: An observationally based evaluation of cloud ice water in CMIP3 and CMIP5 GCMs and contemporary reanalyses using contemporary satellite data, J. Geophys. Res., 117, D16105, https://doi.org/10.1029/2012JD017640, 2012.

Liou, K. N., Takano, Y., He, C., Yang, P., Leung, L. R., Gu, Y., and Lee, W. L.: Stochastic parameterization for light absorption by internally mixed BC/dust in snow grains for application to climate models, J. Geophys. Res.-Atmos., 119, 7616-7632, https://doi.org/10.1002/2014jd021665, 2014.

Liu, H., Jacob, D. J., Bey, I., and Yantosca, R. M.: Constraints from $210 \mathrm{~Pb}$ and $7 \mathrm{Be}$ on wet deposition and transport in a global three-dimensional chemical tracer model driven by assimilated meteorological fields, J. Geophys. Res., 106, 1210912128, https://doi.org/10.1029/2000JD900839, 2001.

Liu, J., Fan, S., Horowitz, L. W., and Levy, H.: Evaluation of factors controlling long-range transport of black carbon to the Arctic, J. Geophys. Res., 116, D04307, https://doi.org/10.1029/2010JD015145, 2011.

Malm, W. C., Sisler, J. F., Huffman, D., Eldred, R. A., and Cahill, T. A.: Spatial and Seasonal Trends in Particle Concentration and Optical Extinction in the United-States, J. Geophys. Res., 99, 1347-1370, https://doi.org/10.1029/93jd02916, 1994.

Mao, Y. H., Li, Q. B., Zhang, L., Chen, Y., Randerson, J. T., Chen, D., and Liou, K. N.: Biomass burning contribution to black carbon in the Western United States Mountain Ranges, Atmos. Chem. Phys., 11, 11253-11266, https://doi.org/10.5194/acp-1111253-2011, 2011.

Mao, Y. H., Li, Q. B., Chen, D., Zhang, L., Hao, W.-M., and Liou, K.-N.: Top-down estimates of biomass burning emissions of black carbon in the Western United States, Atmos. Chem. Phys., 14, 7195-7211, https://doi.org/10.5194/acp-147195-2014, 2014.

Mori, T., Kondo, Y., Ohata, S., Moteki, N., Matsui, H., Oshima, N., and Iwasaki, A.: Wet deposition of black carbon at a remote site in the East China Sea, J. Geophys. Res.-Atmos., 119, 1048510498, https://doi.org/10.1002/2014jd022103, 2014.

Morrison, H., de Boer, G., Feingold, G., Harrington, J., Shupe, M. D., and Sulia, K.: Resilience of persistent Arctic mixed-phase clouds, Nat. Geosci., 5, 11-17, https://doi.org/10.1038/ngeo1332, 2012.

Moteki, N., Kondo, Y., Oshima, N., Takegawa, N., Koike, M., Kita, K., Matsui, H., and Kajino, M.: Size dependence of wet removal of black carbon aerosols during transport from the boundary layer to the free troposphere, Geophys. Res. Lett., 39, L13802, https://doi.org/10.1029/2012GL052034, 2012.
Murray, B. J., O'Sullivan, D., Atkinson, J. D., and Webb, M. E.: Ice nucleation by particles immersed in supercooled cloud droplets, Chem. Soc. Rev., 41, 6519-6554, https://doi.org/10.1039/C2CS35200A, 2012.

Myhre, G., Samset, B. H., Schulz, M., Balkanski, Y., Bauer, S., Berntsen, T. K., Bian, H., Bellouin, N., Chin, M., Diehl, T., Easter, R. C., Feichter, J., Ghan, S. J., Hauglustaine, D., Iversen, T., Kinne, S., Kirkevåg, A., Lamarque, J.-F., Lin, G., Liu, X., Lund, M. T., Luo, G., Ma, X., van Noije, T., Penner, J. E., Rasch, P. J., Ruiz, A., Seland, Ø., Skeie, R. B., Stier, P., Takemura, T., Tsigaridis, K., Wang, P., Wang, Z., Xu, L., Yu, H., Yu, F., Yoon, J.-H., Zhang, K., Zhang, H., and Zhou, C.: Radiative forcing of the direct aerosol effect from AeroCom Phase II simulations, Atmos. Chem. Phys., 13, 1853-1877, https://doi.org/10.5194/acp13-1853-2013, 2013.

Niu, J., Carey, L. D., Yang, P., and Vonder Haar, T. H.: Optical properties of a vertically inhomogeneous mid-latitude mid-level mixed-phase altocumulus in the infrared region, Atmos. Res., 88, 234-242, https://doi.org/10.1016/j.atmosres.2007.11.020, 2008.

Noone, K. J. and Clarke, A. D.: Soot Scavenging Measurements in Arctic Snowfall, Atmos. Environ., 22, 2773-2778, https://doi.org/10.1016/0004-6981(88)90444-1, 1988.

Ogren, J. A., Heintzenberg, J., and Charlson, R. J.: In-situ sampling of clouds with a droplet to aerosol converter, Geophys. Res. Lett., 12, 121-124, https://doi.org/10.1029/GL012i003p00121, 1985.

Park, R. J., Jacob, D. J., Chin, M., and Martin, R. V.: Sources of carbonaceous aerosols over the United States and implications for natural visibility, J. Geophys. Res., 108, 4355, https://doi.org/10.1029/2002JD003190, 2003.

Park, R. J., Jacob, D. J., Palmer, P. I., Clarke, A. D., Weber, R. J., Zondlo, M. A., Eisele, F. L., Bandy, A. R., Thornton, D. C., Sachse, G. W., and Bond, T. C.: Export efficiency of black carbon aerosol in continental outflow: Global implications, J. Geophys. Res., 110, D11205, https://doi.org/10.1029/2004JD005432, 2005.

Pinto, J. O.: Autumnal Mixed-Phase Cloudy Boundary Layers in the Arctic, J. Atmos. Sci., 55, 2016-2038, https://doi.org/10.1175/1520-0469, 1998.

Pio, C. A., Legrand, M., Oliveira, T., Afonso, J., Santos, C., Caseiro, A., Fialho, P., Barata, F., Puxbaum, H., SanchezOchoa, A., Kasper-Giebl, A., Gelencsér, A., Preunkert, S., and Schock, M.: Climatology of aerosol composition (organic versus inorganic) at nonurban sites on a west-east transect across Europe, J. Geophys. Res., 112, D23S02, https://doi.org/10.1029/2006JD008038, 2007.

Pruppacher, H. R. and Klett, J. D.: Microphysics of clouds and precipitation, in: Atmospheric and Oceanographic Sciences Library, Springer Netherlands, 18, 954 pp., https://doi.org/10.1007/9780-306-48100-0, 2010.

Qi, L., Li, Q., Li, Y., and He, C.: Factors controlling black carbon distribution in the Arctic, Atmos. Chem. Phys., 17, 1037-1059, https://doi.org/10.5194/acp-17-1037-2017, 2017.

Ramanathan, V. and Carmichael, G.: Global and regional climate changes due to black carbon, Nat. Geosci., 1, 221-227, 2008.

Randerson, J. T., Chen, Y., van der Werf, G. R., Rogers, B. M., and Morton, D. C.: Global burned area and biomass burning emissions from small fires, J. Geophys. Res., 117, G04012, https://doi.org/10.1029/2012JG002128, 2012. 
Samset, B. H. and Myhre, G.: Vertical dependence of black carbon, sulphate and biomass burning aerosol radiative forcing, Geophys. Res. Lett., 38, L24802, https://doi.org/10.1029/2011GL049697, 2011.

Schulz, M., Textor, C., Kinne, S., Balkanski, Y., Bauer, S., Berntsen, T., Berglen, T., Boucher, O., Dentener, F., Guibert, S., Isaksen, I. S. A., Iversen, T., Koch, D., Kirkevåg, A., Liu, X., Montanaro, V., Myhre, G., Penner, J. E., Pitari, G., Reddy, S., Seland, Ø., Stier, P., and Takemura, T.: Radiative forcing by aerosols as derived from the AeroCom present-day and pre-industrial simulations, Atmos. Chem. Phys., 6, 5225-5246, https://doi.org/10.5194/acp6-5225-2006, 2006.

Schwarz, J. P., Gao, R. S., Spackman, J. R., Watts, L. A., Thomson, D. S., Fahey, D. W., Ryerson, T. B., Peischl, J., Holloway, J. S., Trainer, M., Frost, G. J., Baynard, T., Lack, D. A., de Gouw, J. A., Warneke, C., and Del Negro, L. A.: Measurement of the mixing state, mass, and optical size of individual black carbon particles in urban and biomass burning emissions, Geophys. Res. Lett., 35, L13810, https://doi.org/10.1029/2008GL033968, 2008.

Schwarz, J. P., Spackman, J. R., Gao, R. S., Watts, L. A., Stier, P., Schulz, M., Davis, S. M., Wofsy, S. C., and Fahey, D. W.: Global-scale black carbon profiles observed in the remote atmosphere and compared to models, Geophys. Res. Lett., 37, L18812, https://doi.org/10.1029/2010GL044372, 2010.

Sellegri, K., Laj, P., Dupuy, R., Legrand, M., Preunkert, S., and Putaud, J. P.: Size-dependent scavenging efficiencies of multicomponent atmospheric aerosols in clouds, J. Geophys. Res., 108, 4334, https://doi.org/10.1029/2002JD002749, 2003.

Shupe, M. D., Matrosov, S. Y., and Uttal, T.: Arctic Mixed-Phase Cloud Properties Derived from SurfaceBased Sensors at SHEBA, J. Atmos. Sci., 63, 697-711, https://doi.org/10.1175/JAS3659.1, 2006.

Smith, A. J., Larson, V. E., Niu, J., Kankiewicz, J. A., and Carey, L. D.: Processes that generate and deplete liquid water and snow in thin midlevel mixed-phase clouds, J. Geophys. Res., 114, D12203, https://doi.org/10.1029/2008JD011531, 2009.

Stier, P., Feichter, J., Kinne, S., Kloster, S., Vignati, E., Wilson, J., Ganzeveld, L., Tegen, I., Werner, M., Balkanski, Y., Schulz, M., Boucher, O., Minikin, A., and Petzold, A.: The aerosol-climate model ECHAM5-HAM, Atmos. Chem. Phys., 5, 1125-1156, https://doi.org/10.5194/acp-5-1125-2005, 2005.

Stohl, A., Klimont, Z., Eckhardt, S., Kupiainen, K., Shevchenko, V. P., Kopeikin, V. M., and Novigatsky, A. N.: Black carbon in the Arctic: the underestimated role of gas flaring and residential combustion emissions, Atmos. Chem. Phys., 13, 8833-8855, https://doi.org/10.5194/acp-13-8833-2013, 2013.

Tan, I., Storelvmo, T., and Zelinka, M. D.: Observational constraints on mixed-phase clouds imply higher climate sensitivity, Science, 352, 224-227, https://doi.org/10.1126/science.aad5300, 2016.

Taylor, J. W., Allan, J. D., Allen, G., Coe, H., Williams, P. I., Flynn, M. J., Le Breton, M., Muller, J. B. A., Percival, C. J., Oram, D., Forster, G., Lee, J. D., Rickard, A. R., Parrington, M., and Palmer, P. I.: Size-dependent wet removal of black carbon in Canadian biomass burning plumes, Atmos. Chem. Phys., 14, 13755-13771, https://doi.org/10.5194/acp-14-137552014, 2014

Textor, C., Schulz, M., Guibert, S., Kinne, S., Balkanski, Y., Bauer, S., Berntsen, T., Berglen, T., Boucher, O., Chin, M., Dentener, F., Diehl, T., Easter, R., Feichter, H., Fillmore, D., Ghan, S., Ginoux,
P., Gong, S., Grini, A., Hendricks, J., Horowitz, L., Huang, P., Isaksen, I., Iversen, I., Kloster, S., Koch, D., Kirkevåg, A., Kristjansson, J. E., Krol, M., Lauer, A., Lamarque, J. F., Liu, X., Montanaro, V., Myhre, G., Penner, J., Pitari, G., Reddy, S., Seland, Ø., Stier, P., Takemura, T., and Tie, X.: Analysis and quantification of the diversities of aerosol life cycles within AeroCom, Atmos. Chem. Phys., 6, 1777-1813, https://doi.org/10.5194/acp-6-17772006, 2006.

Wang, Q., Jacob, D. J., Fisher, J. A., Mao, J., Leibensperger, E. M., Carouge, C. C., Le Sager, P., Kondo, Y., Jimenez, J. L., Cubison, M. J., and Doherty, S. J.: Sources of carbonaceous aerosols and deposited black carbon in the Arctic in winter-spring: implications for radiative forcing, Atmos. Chem. Phys., 11, 1245312473, https://doi.org/10.5194/acp-11-12453-2011, 2011.

Wang, Q., Jacob, D. J., Spackman, J. R., Perring, A. E., Schwarz, J. P., Moteki, N., Marais, E. A., Ge, C., Wang, J., and Barrett, S. R. H.: Global budget and radiative forcing of black carbon aerosol: Constraints from pole-to-pole (HIPPO) observations across the Pacific, J. Geophys. Res.-Atmos., 119, 195-206, https://doi.org/10.1002/2013JD020824, 2014

Wang, X., Heald, C. L., Ridley, D. A., Schwarz, J. P., Spackman, J. R., Perring, A. E., Coe, H., Liu, D., and Clarke, A. D.: Exploiting simultaneous observational constraints on mass and absorption to estimate the global direct radiative forcing of black carbon and brown carbon, Atmos. Chem. Phys., 14, 10989-11010, https://doi.org/10.5194/acp-14-10989-2014, 2014.

Wang, X., Doherty, S. J., and Huang, J. P.: Black carbon and other light-absorbing impurities in snow across Northern China, J. Geophys. Res.-Atmos., 118, 1471-1492, https://doi.org/10.1029/2012jd018291, 2013.

Wang, X., Xu, B. Q., and Ming, J.: An Overview of the Studies on Black Carbon and Mineral Dust Deposition in Snow and Ice Cores in East Asia, Journal of Meteorological Research, 28, 354 370, https://doi.org/10.1007/S13351-014-4005-7, 2014.

Wang, Z. W., Gallet, J. C., Pedersen, C. A., Zhang, X. S., Ström, J., and Ci, Z. J.: Elemental carbon in snow at Changbai Mountain, northeastern China: concentrations, scavenging ratios, and dry deposition velocities, Atmos. Chem. Phys., 14, 629-640, https://doi.org/10.5194/acp-14-629-2014, 2014.

Wegener, A.: Thermodynamik der Atmosphäre, J. A. Barth, Leipzig, 331 pp., 1911.

Weingartner, E., Burtscher, H., and Baltensperger, U.: Hygroscopic properties of carbon and diesel soot particles, Atmos. Environ., 31, 2311-2327, https://doi.org/10.1016/S1352-2310(97)00023X, 1997.

Wesely, M. L.: Parameterization of Surface Resistances to Gaseous Dry Deposition in Regional-Scale Numerical-Models, Atmos. Environ., 23, 1293-1304, https://doi.org/10.1016/00046981(89)90153-4, 1989.

Wyslouzil, B. E., Carleton, K. L., Sonnenfroh, D. M., Rawlins, W. T., and Arnold, S.: Observation of hydration of single, modified carbon aerosols, Geophys. Res. Lett., 21, 2107-2110, https://doi.org/10.1029/94GL01588, 1994.

Ye, H., Zhang, R. D., Shi, J. S., Huang, J. P., Warren, S. G., and $\mathrm{Fu}, \mathrm{Q}$.: Black carbon in seasonal snow across northern Xinjiang in northwestern China, Environ. Res. Lett., 7, 044002, https://doi.org/10.1088/1748-9326/7/4/044002, 2012.

Zhang, D., Wang, Z., and Liu, D.: A global view of midlevel liquidlayer topped stratiform cloud distribution and phase partition 
from CALIPSO and CloudSat measurements, J. Geophys. Res., 115, D00H13, https://doi.org/10.1029/2009jd012143, 2010.

Zhang, L. M., Gong, S. L., Padro, J., and Barrie, L.: A size-segregated particle dry deposition scheme for an atmospheric aerosol module, Atmos. Environ., 35, 549-560, https://doi.org/10.1016/S1352-2310(00)00326-5, 2001.

Zhang, Q., Streets, D. G., Carmichael, G. R., He, K. B., Huo, H., Kannari, A., Klimont, Z., Park, I. S., Reddy, S., Fu, J. S., Chen, D., Duan, L., Lei, Y., Wang, L. T., and Yao, Z. L.: Asian emissions in 2006 for the NASA INTEX-B mission, Atmos. Chem. Phys., 9, 5131-5153, https://doi.org/10.5194/acp-9-5131-2009, 2009.

Zhang, R., Khalizov, A. F., Pagels, J., Zhang, D., Xue, H., and McMurry, P. H.: Variability in morphology, hygroscopicity, and optical properties of soot aerosols during atmospheric processing, P. Natl. Acad. Sci. USA, 105, 10291-10296, https://doi.org/10.1073/pnas.0804860105, 2008.
Zhang, R., Hegg, D. A., Huang, J., and Fu, Q.: Source attribution of insoluble light-absorbing particles in seasonal snow across northern China, Atmos. Chem. Phys., 13, 6091-6099, https://doi.org/10.5194/acp-13-6091-2013, 2013.

Zhang, X. Y., Wang, Y. Q., Zhang, X. C., Guo, W., and Gong, S. L.: Carbonaceous aerosol composition over various regions of China during 2006, J. Geophys. Res.-Atmos., 113, D14111, https://doi.org/10.1029/2007jd009525, 2008. 